Review

\title{
The Role of $n-3$ Polyunsaturated Fatty Acids in the Prevention and Treatment of Breast Cancer
}

\author{
Jiajie Liu and David W. L. Ma * \\ Department of Human Health \& Nutritional Sciences, College of Biological Sciences, University of \\ Guelph, Guelph, ON N1G 2W1, Canada; E-Mail: jliu22@uoguelph.ca \\ * Author to whom correspondence should be addressed; E-Mail: davidma@uoguelph.ca; \\ Tel.: +1-519-824-4120 (ext. 52272); Fax: +1-519-763-5902.
}

Received: 27 August 2014; in revised form: 28 October 2014 / Accepted: 4 November 2014 / Published: 18 November 2014

\begin{abstract}
Breast cancer (BC) is the most common cancer among women worldwide. Dietary fatty acids, especially $n-3$ polyunsaturated fatty acids (PUFA), are believed to play a role in reducing $\mathrm{BC}$ risk. Evidence has shown that fish consumption or intake of long-chain $n$-3 PUFA, such as eicosapentaenoic acid (EPA) and docosahexaenoic acid (DHA), are beneficial for inhibiting mammary carcinogenesis. The evidence regarding $\alpha$-linolenic acid (ALA), however, remains equivocal. It is essential to clarify the relation between ALA and cancer since ALA is the principal source of $n-3$ PUFA in the Western diet and the conversion of ALA to EPA and DHA is not efficient in humans. In addition, the specific anticancer roles of individual $n$-3 PUFA, alone, have not yet been identified. Therefore, the present review evaluates ALA, EPA and DHA consumed individually as well as in $n$-3 PUFA mixtures. Also, their role in the prevention of $\mathrm{BC}$ and potential anticancer mechanisms of action are examined. Overall, this review suggests that each $n$-3 PUFA has promising anticancer effects and warrants further research.
\end{abstract}

Keywords: $n-3$ polyunsaturated fatty acids (PUFA); eicosapentaenoic acid (EPA); docosahexaenoic acid (DHA); $\alpha$-linolenic acid (ALA); mammary gland; breast cancer (BC)

\section{Introduction}

Breast cancer $(\mathrm{BC})$ is a major health problem among women worldwide, and is the second leading cause of death for women in Canada and the United States [1,2]. On average, 65 Canadian women will 
be diagnosed with BC per day, with 1 in 9 females expected to develop BC in their lifetime [1,2]. Both genetic and environmental factors are believed to play a role in a woman's risk of developing BC $[3,4]$. Most anticancer drugs, developed to date, aim to kill cancer cells and decrease tumor burden but are relatively ineffective against some phases of tumorigenesis $[5,6]$. Thus, alternate strategies to prevent tumorigenesis are urgently required. In the past few decades, epidemiological studies have suggested that a healthy diet and lifestyle are critical for the prevention of BC. Dietary fatty acids are one of the most intensively studied dietary factors [7-9].

Saturated fatty acids (SFA), monounsaturated fatty acids (MUFA) and trans fatty acids (TFA) have been found to increase cancer risk; while specific polyunsaturated fatty acids (PUFA) are indicated to have anticancer effects [9,10]. There are two major classes of PUFA: $n-6$ PUFA and $n-3$ PUFA. In mammals, $n-6$ and $n-3$ PUFA are both essential fatty acids for health and must be consumed as part of the diet because they cannot be endogenously synthesized [11]. Linoleic acid (LA, 18:2n-6) and arachidonic acid (AA, 20:4n-6) are the two most common n-6 PUFA in typical Western diets; LA can be found in some plant oils such as corn and safflower oils, and AA usually comes from dietary animal sources or can be synthesized from LA [12,13]. $\alpha$-linolenic acid (ALA, 18:3n-3) is the precursor of the $n$-3 PUFA family which can be further elongated and desaturated to two important long chain n-3 PUFA, eicosapentaenoic acid (EPA, 20:5n-3) and docosahexaenoic acid (DHA, 22:6n-3) [11]. ALA is a plant-derived $n-3$ PUFA, which is present in flaxseed, canola and soybean oils [14]. The longer chain $n-3$ PUFA, EPA and DHA can be obtained directly from marine sources such as seafood and fish oils, and are widely known for their cardioprotective benefit [13]. ALA is the major $n$-3 PUFA consumed in the Western diet, whereas intakes of EPA and DHA are typically low. It is estimated that the typical North American diet provides approximately $1.4 \mathrm{~g}$ of ALA and $0.1-0.2 \mathrm{~g}$ of EPA plus DHA per day [15]. With regard to dietary reference intake of $n$-3 PUFA, the Institute of Medicine (IOM) recommends since 2005 a daily intake $1.1 \mathrm{~g}$ ALA for women and $1.6 \mathrm{~g}$ ALA for men to prevent some chronic diseases, and up to ten percent of this can be consumed as EPA and/or DHA [16]. While current intakes meet IOM recommendations, in a 2014 report by the Academy of Nutrition and Dietetics, $500 \mathrm{mg}$ EPA plus DHA per day is required for the general healthy adult population [17].

Results from both in vivo and in vitro studies suggest that $n-6$ PUFA accelerate tumorigenesis, in contrast, $n$-3 PUFA may have anticancer effects [18-22]. Western diets are typically deficient in $n-3$ PUFA and high in $n$-6 PUFA compared with traditional Asian diets [8,23,24]. Migration studies have shown that Asian women, who typically have a lower rate of BC and higher fish consumption exhibited an increased incidence of BC within one generation after migration to the Western countries [24,25]. Historically, the intake of $n-6$ and $n-3$ PUFA has been estimated to be approximately equal. However, in recent years, the content of Western diets has significantly increased in $n-6$ PUFA resulting in an increase in the $n-6 / n-3$ PUFA ratio [8]. Excessive amounts of $n-6$ PUFA and a very high $n-6 / n-3$ ratio (16:1 or higher), as is currently found in Western diets, have been suggested to promote the pathogenesis of many diseases such as cardiovascular disease, autoimmune diseases and some types of cancer; whereas increased levels of $n$-3 PUFA (a low $n-6 / n-3$ ratio) have been shown to exert suppressive effects [8]. However, it remains to be resolved whether it is simply the reduced $n-3$ PUFA or the changing $n-6 / n-3$ ratio that is relevant to these outcomes. 
Substantial evidence from cell culture and rodent studies indicate that increased fish consumption or intake of $n$-3 PUFA inhibits BC cell proliferation and reduces BC risk relative to $n$-6 PUFA [26-30]. Nevertheless, there has been longstanding controversy in epidemiological and observational studies regarding the potential anticancer effects of $n-3$ PUFA due to the inability to show causality. Previous published reviews have focused on the role of fish and marine $n-3$ fatty acids in BC prevention, whereas the evidence for ALA and individual effects of long chain $n-3$ PUFA is lacking [3,8,11,23,31-34]. Since a typical North American diet is mainly comprised of ALA as the source of $n-3$ PUFA, it is necessary to elucidate the specific effects of ALA and cancer risk. Therefore, the purpose of the present review is to evaluate the preventative role of ALA, EPA and DHA in BC development when consumed individually, as well as in $n$-3 PUFA mixtures through dietary and supplemental forms. In addition, the potential mechanisms by which they exert anticancer effects will also be discussed.

\section{The Effects of $\boldsymbol{n - 3}$ PUFA in Human BC Studies}

Dietary $n$-3 PUFA may influence breast cancer (BC) progression and prognosis. In the past ten years, six prospective cohort studies (Table 1) and nine case-control studies (Table 2) have examined the association between the consumption of either fish or fish oil supplements and BC risk, showing a protective effect of $n-3$ PUFA. These studies were conducted in many different geographic areas with mixed findings. In general, Asian populations with a low total fat intake and high fish consumption, associated $n$-3 PUFA intake with a reduced risk of BC [35-39]. There was also a weak association with reduced $\mathrm{BC}$ risk in US studies involving women whose diets had higher $n-6$ PUFA content combined with fish oil supplements $[18,40,41]$. European studies were less consistent and somewhat contradictory [42-45].

In the Japan Collaborative Cohort (JACC) study, a significant decrease in the risk of BC was detected in women with the highest dietary intake of fish fat and the long-chain $n$-3 PUFA [35]. Similar results were observed in a large prospective study of 35,298 Singapore women, indicating an inverse association between dietary $n$-3 PUFA from marine sources and BC risk [36]. Relative to the lowest quartile of $n$-3 PUFA intake, individuals in the top three quartiles exhibited a $26 \%$ reduction in $\mathrm{BC}$ risk (relative risk $=0.74 ; 95 \%$ confidence interval $=0.58-0.94$ ). Additionally, a recent analysis from the VITamins And Lifestyle (VITAL) cohort carried out in US indicated that the current use of fish oil supplements was associated with a decreased risk of localized invasive ductal carcinomas in postmenopausal women [40]. 
Table 1. $n$-3 PUFA and breast cancer risk: Prospective cohort studies.

\begin{tabular}{|c|c|c|c|c|c|c|}
\hline Year & Country & Subjects & $\begin{array}{c}\text { Method of } \\
\text { Assessment }\end{array}$ & n-3/n-6 PUFA Source & BC Risk & Reference \\
\hline 2005 & Japan & $\begin{array}{c}26,291 \text { women } \\
40-79 \text { years } \\
129 \text { BC cases } \\
\end{array}$ & $\mathrm{FFQ}^{1}$ & $\begin{array}{l}\text { Animal and fish fat, vegetable oil, } \\
\text { SFA, MUFA and PUFA }\end{array}$ & $\uparrow$ fish fat, EPA + DHA $\downarrow$ BC risk & [35] \\
\hline 2003 & Singapore & $\begin{array}{l}35,298 \text { women } \\
45-74 \text { years } \\
342 \text { BC cases }\end{array}$ & FFQ & $\begin{array}{l}\text { Fish/shellfish, saturated, } \\
\text { monounsaturated and } \\
\text { polyunsaturated fat }\end{array}$ & $\begin{array}{l}\uparrow n \text {-3 PUFA from fish/shellfish } \downarrow \text { BC risk } \\
\uparrow n \text {-6 PUFA ( low marine } n-3 \text { ) } \uparrow \text { BC risk }\end{array}$ & [36] \\
\hline 2010 & US & $\begin{array}{c}\text { 35,016 postmenopausal } \\
50-76 \text { years } \\
880 \text { BC cases } \\
\end{array}$ & FFQ & Dietary fish oil supplement & $\begin{array}{c}\uparrow \text { fish oil } \downarrow \text { risk of invasive ductal } \\
\text { carcinomas }\end{array}$ & [40] \\
\hline 2009 & France & $\begin{array}{c}56,007 \text { women } \\
40-65 \text { years } \\
1650 \text { BC case } \\
\end{array}$ & FFQ & $\begin{array}{l}\text { ALA and } n-6 \text { PUFA from fruit, nuts } \\
\text { and vegetable oils; Long chain } n-3 \\
\text { PUFA from meals }\end{array}$ & $\begin{array}{c}\text { no association between total } n \text { - } 3 \text { and BC risk } \\
\uparrow \text { ALA } \downarrow \text { BC risk } \uparrow \text { long chain } n \text {-3 PUFA } \\
\downarrow \text { BC risk (at highest quintile of } n \text { - } 6 \text { PUFA) }\end{array}$ & {$[42]$} \\
\hline 2003 & Denmark & $\begin{array}{c}23,693 \text { postmenopausal } \\
50-64 \text { years } \\
424 \text { BC cases } \\
\end{array}$ & FFQ & Fish & $\uparrow$ intake of fish $\uparrow \mathrm{ER}+\mathrm{BC}$ incidence & [43] \\
\hline 2011 & China & $\begin{array}{l}72,571 \text { women } \\
40-70 \text { years } \\
712 \text { BC cases }\end{array}$ & FFQ & $\begin{array}{l}\text { Fish, marine-derived } \\
n-3 \text { PUFA red meat }\end{array}$ & $\uparrow n-6 / n-3$ PUFA ratio $\uparrow \mathrm{BC}$ risk & [37] \\
\hline
\end{tabular}

${ }^{1}$ FFQ: food frequency questionnaire; $\uparrow$ : increase; $\downarrow$ : decrease. 
Table 2. n-3 PUFA and breast cancer risk: Case-control studies.

\begin{tabular}{|c|c|c|c|c|c|c|}
\hline Year & Country & Subjects Characteristics & $\begin{array}{l}\text { Method of } \\
\text { Assessment }\end{array}$ & n-3/n-6 PUFA Source & BC Risk & Reference \\
\hline 2007 & Japan & $\begin{array}{l}103 \text { incident } \mathrm{BC} \text { cases } \\
309 \text { controls }\end{array}$ & $\begin{array}{c}\text { erythrocyte } \\
\text { membrane FFQ }\end{array}$ & $\begin{array}{l}\text { dietary food intake including } \\
\text { soy and meat products, fish } \\
\text { and other seafood, vegetables }\end{array}$ & $\begin{array}{c}\uparrow \text { dietary intake of } n \text { - } 3 \text { fatty acids } \downarrow \text { BC risk } \\
\uparrow \text { long chain } n \text {-3 PUFA in erythrocyte } \downarrow \text { BC risk } \\
\uparrow \text { saturated fatty } \uparrow \text { BC risk }\end{array}$ & {$[46]$} \\
\hline 2007 & China & $\begin{array}{l}322 \text { incident } \mathrm{BC} \text { cases } \\
1030 \text { controls }\end{array}$ & $\begin{array}{l}\text { erythrocyte } \\
\text { membrane }\end{array}$ & & $\uparrow$ total $n$ - 3 fatty acids and EPA $\downarrow$ BC risk & {$[47]$} \\
\hline 2009 & China & $\begin{array}{c}155 \mathrm{NPFC}^{1} \\
185 \mathrm{PFC}^{2} \\
241 \mathrm{BC}, 1030 \text { controls } \\
\end{array}$ & $\begin{array}{c}\text { erythrocyte } \\
\text { membrane FFQ }\end{array}$ & dietary food intake & $\begin{array}{c}\uparrow \text { EPA } \downarrow \text { risk of NPFC } \\
\downarrow \text { progression of PFC to BC } \\
\uparrow \gamma \text {-linolenic acid } \uparrow \text { risk of NPFC, PFC and BC }\end{array}$ & {$[38]$} \\
\hline 2002 & US & $\begin{array}{c}73 \mathrm{BC} \text { patients } \\
74 \text { controls } \\
\end{array}$ & $\begin{array}{c}\text { breast } \\
\text { adipose tissue }\end{array}$ & & $\begin{array}{c}\uparrow \text { EPA and DHA } \downarrow n-6 / n-3 \text { PUFA ratio } \downarrow \text { BC risk } \\
\uparrow n \text { - } 6 \text { PUFA } \uparrow \text { BC risk }\end{array}$ & {$[18]$} \\
\hline 2003 & US & $\begin{array}{l}565 \text { incident } \mathrm{BC} \\
554 \text { controls }\end{array}$ & FFQ & daily fat intake & $\begin{array}{c}\downarrow n-6 / n-3 \text { PUFA ratio } \downarrow \text { BC risk (premenopausal) } \\
\uparrow \text { EPA, DHA } \downarrow \text { BC risk (21\% and 18\%, respectively) }\end{array}$ & {$[41]$} \\
\hline 2009 & Denmark & $\begin{array}{l}463 \text { BC cases } \\
1098 \text { controls }\end{array}$ & $\begin{array}{l}\text { Gluteal adipose } \\
\text { tissue biopsy }\end{array}$ & dietary food intake & $\begin{array}{c}\text { No association between total or individual marine } \\
n-3 \text { PUFA in adipose tissue and risk of } \mathrm{BC}\end{array}$ & [44] \\
\hline 2002 & France & $\begin{array}{l}241 \text { invasive } \mathrm{BC} \text { cases } \\
88 \text { controls-benign breast disease }\end{array}$ & $\begin{array}{c}\text { breast } \\
\text { adipose tissue }\end{array}$ & & $\uparrow \mathrm{ALA} \uparrow \mathrm{DHA} \downarrow n-6 / n-3$ PUFA ratio $\downarrow$ BC risk & {$[45]$} \\
\hline 2012 & Mexican & $\begin{array}{l}1000 \text { incident } \mathrm{BC} \text { cases } \\
1074 \text { controls }\end{array}$ & $\begin{array}{l}\text { Interview } \\
\text { and FFQ }\end{array}$ & dietary food intake & $\begin{array}{l}\uparrow n-3 \text { PUFA } \downarrow \text { BC risk (obese women) } \\
\uparrow n-6 \text { PUFA } \uparrow \text { BC risk (premenopausal) }\end{array}$ & [19] \\
\hline 2009 & $\begin{array}{l}\text { South } \\
\text { Korea }\end{array}$ & $\begin{array}{l}358 \text { incident } \mathrm{BC} \text { patients } \\
360 \text { controls }\end{array}$ & FFQ & fatty and lean fish & $\begin{array}{c}\uparrow \text { fatty fish consumption } \downarrow \text { BC risk } \\
\uparrow E P A \text { and DHA derived from fish } \downarrow \text { BC risk }\end{array}$ & {$[39]$} \\
\hline
\end{tabular}

${ }^{1}$ Benign proliferative fibrocystic conditions (PFC); ${ }^{2}$ non-proliferative fibrocystic conditions (NPFC); $\uparrow:$ increase; $\downarrow$ : decrease. 
The association between dietary intakes of $n$-3 PUFA or fish oil supplements with overall survival was also examined. Patterson et al. demonstrated that women with higher intakes of EPA and DHA from food, but not from fish oil supplements, had a dose-dependent reduction in all-cause mortality [48]. They also showed a reduced risk of additional $\mathrm{BC}$ events of approximately $25 \%$ when compared with the lowest tertile of intake (tertile 3 :hazard ratio $=0.72 ; 95 \%$ confidence interval $=0.57-0.90$ ) [48]. In support of these self-reported intake studies, Zheng et al. performed a comprehensive analysis of 21 independent prospective cohort studies and found that marine $n$-3 PUFA were associated with a $14 \%$ risk reduction of $\mathrm{BC}$, and the relative risk remained similar whether marine $n-3$ PUFA was measured as dietary intake or as tissue biomarkers [7]. Further, a dose-response analysis indicated a $5 \%$ lower risk of BC per $0.1 \mathrm{~g} /$ day $\left(0.95,0.90\right.$ to $\left.1.00, I^{2}=52 \%\right)$ increment of dietary marine $n$-3 PUFA [7]. Conversely, a French study comprising over 56,000 women found no association between total $n-3$ or $n-6$ PUFA intake and BC risk [42]. Also, a large study of postmenopausal women in Denmark concluded that increased fish consumption was associated with elevated incidence rates of $\mathrm{BC}$, but this association was present only for development of estrogen positive BC [43]. These null studies were mostly conducted in European populations with relatively low per capita intake of $n$-3 PUFA [32,44].

In order to examine the relationship between $n$-3 PUFA exposure and BC risk, several case-control studies have been conducted using different biomarkers (Table 2). Kuriki et al. investigated the fatty acid compositions of erythrocyte membranes as a biomarker and demonstrated that $\mathrm{BC}$ risk exhibited a significant inverse association with dietary intake of $n-3$ PUFA derived from fish and high levels of long-chain n-3 PUFA in erythrocyte membranes [46]. Another assessment of erythrocyte fatty acid composition found the inverse association significant only for EPA and total $n$-3 PUFA content [47]. Furthermore, Shannon et al. evaluated the role of $n-3$ and $n-6$ PUFA in the development of benign proliferative fibrocystic conditions (PFC) and non-proliferative fibrocystic conditions (NPFC) in the breast [38]. They showed that women in the highest quartile of erythrocyte EPA concentrations were $67 \%$ less likely to have NPFC alone or with BC, and EPA significantly lowered the risk of progressing from PFC to BC by 43\% [38]. However, $\gamma$-linolenic acid ( $n-6$ PUFA) was found to be positively associated with nearly all conditions [38]. These results were consistent with an earlier meta-analysis showing that total and individual $n$-3 PUFA, especially EPA and DHA, play a protective effect against BC, while total SFA, MUFA, palmitic and oleic acids were associated with increased BC risk [9].

In a Korean case control study, 358 patients with $\mathrm{BC}$ and 360 healthy controls underwent dietary assessment by questionnaire and interview to determine their dietary consumption of fish and $n-3$ PUFA derived from fish. Both pre- and postmenopausal women in the highest quartile of fatty-fish intake had a lower incidence of $\mathrm{BC}$ (odds ratio $\mathrm{OR}=0.23,95 \% \mathrm{CI}=0.13-0.42 ; p<0.001$ ), but the protective effect of EPA and/or DHA intake was only observed for postmenopausal women [39]. These findings were similarly observed in a study of Mexican women where BC risk was lower in obese women (BMI $\geq 30)$ with high $n$-3 PUFA intake, not in women of normal weight [19]. In contrast, a case-cohort study of Danish women did not find any association between either total or individual marine $n-3$ PUFA intake and $\mathrm{BC}$ risk [44]. As the total levels of marine $n-3$ PUFA intake were low in Europe, this may account for observed discrepancies relative to populations consuming marine-rich diets $[32,44]$.

Other population studies have investigated interactions between $n-3$ and $n-6$ PUFA. Quantifying consumption of both types of fatty acids is an essential step in isolating $n$-3 PUFA specific effects. The study of Bagga et al. showed that excessive intake of $n-6$ PUFA contributed to the high risk 
of $\mathrm{BC}$ in US, while a decreased risk of BC development was accompanied with higher EPA and DHA consumption [18]. A similar inverse relationship was also observed in regard to the $n-6 / n-3$ PUFA ratio. In another US study, when the analysis was restricted to pre-menopausal women, the consumption of the lowest ratio of $n-6$ to $n-3$ was associated with a $41 \%$ reduction of BC risk, although it was not significant [41]. This observation was also observed in studies conducted in China and France, although there was no association between $n-3$ PUFA intake and BC risk, low $n$-3 PUFA intake by women who had the highest $n-6$ PUFA was correlated with elevated BC risk [37,45]. However, based on the ratio, it is not possible to determine whether it is increased $n-6$ or decreased $n-3$ PUFA that is the causal driver of BC risk. Nevertheless, these studies indicate the necessity of higher $n-3$ PUFA intakes given that $n-6$ intakes are adequate in all populations, and thus heightening the potential value of $n-3$ PUFA as effective agents against $\mathrm{BC}$.

Diet intervention by $n$-3 PUFA supplements as a mean of decreasing BC risk in women still needs to be tested clinically. To date, few human intervention studies have assessed the effectiveness of $n$-3 PUFA in BC prevention and treatment. One randomized clinical trial tested the combined effects of $n$-3 PUFA (EPA + DHA = 3.36 g/day, 2 year) and Raloxifene (anti-estrogen) in reducing risk of BC in postmenopausal women [49]. Although the plasma $n-6 / n-3$ ratio significantly decreased among subjects after $n$-3 PUFA intervention compared with the subjects without intervention, $n$-3 PUFA administration did not affect any selected biomarkers that associated with BC risk [49]. While in another human intervention study, Thompson et al. demonstrated that daily intake of $25 \mathrm{~g}$ flaxseed (ALA $=57 \%$ of total fatty acids) can significantly reduce cell proliferation and increase cell apoptosis in tumors of postmenopausal BC patients. These limited results provide encouragement for future study of $n-3$ PUFA as an adjuvant therapy in $\mathrm{BC}[50]$.

\section{PUFA-Potential Mechanisms of Action}

For more than 30 years, numerous studies have attempted to establish whether there is a causal relationship between $n-3$ PUFA ingestion and a reduction in mammary carcinogenesis. Mounting evidence shows that dietary $n$-3 PUFA may exert an anti-carcinogenic action by altering the composition of cell membrane phospholipids, inhibiting AA metabolism and decreasing AA derived eicosanoids, as well as modulating the expression and function of numerous receptors, transcription factors and lipid derived signaling molecules. However, studies of the effects of dietary $n$-3 PUFA on BC progression and prognosis are limited in humans. Epidemiological studies do not allow for the analysis of important cellular interactions and the specific molecular pathways which are activated during the course of tumor initiation and cancer progression in the mammary gland. Thus, the use of animal models (in vivo) and $\mathrm{BC}$ cell lines (in vitro) provide crucial avenues for improving our understanding of the underlying biological pathways involved in trigger BC development and potential therapeutic approaches for BC treatment and prevention. Here we first introduce some potential mechanisms and important downstream mediators that involved in the anticancer action of $n-3$ PUFA.

\subsection{Influence on Cell Plasma Membrane Composition}

Fatty acids play an important role in membrane biogenesis in the form of glycerophospholipids, a major class of lipids found all cell membranes [51]. Dietary PUFA integrate into plasma membrane 
glycerophosholipids and influence the fatty acid composition [52]. The $s n-1$ position on the glycerol backbone of glycerophospholipids is usually linked to saturated fatty acids, and the $s n-2$ position is linked to an $n-6$ PUFA such as AA. Increased intake of dietary $n$-3 PUFA may replace $n-6$ with $n-3$ fatty acids at the $s n-2$ position of glycerophospholipids [52]. Since $n-3$ PUFA has a greater density compared to $n-6$ PUFA, the aggregation of $n-3$ fatty acids tend to be closer to the lipid-water interface of the membrane. This characteristic can significantly affect plasma membrane fluidity and permeability [53]. In addition, due to the high level unsaturation of long chain $n$-3 PUFA, they have very poor affinity for cholesterol [52,54]. Membrane cholesterol serves as a spacer for the hydrocarbon chains of sphingolipids and maintains the assembled microdomains of lipid rafts [55]. Thus, cholesterol depletion leads to the disorganization of lipid raft structure [54]. Lipid rafts are important membrane domains for cell signaling since it is enriched with many regulatory proteins and some growth factor receptors. [54,55] As a result, the incorporation of $n-3$ PUFA, especially EPA and DHA, can disturb formation of lipid rafts and suppress raft-associated cell signal transduction [22,56,57].

\subsection{Inhibition of Arachidonic Acid (AA) Derived Eicosanoid Biosynthesis}

One of the key cellular functions of PUFA is related to their enzymatic conversion into eicosanoids. Eicosanoids are short-lived, hormone-like lipids, typically comprised of 20 carbon atoms, which play a critical role in platelet aggregation, cellular growth and cell differentiation [31]. The most salient mechanism by which $n$-3 PUFA reduce tumor development is through inhibiting the synthesis of inflammatory eicosanoids derived from AA [31]. As indicated in Figure 1, firstly, both ALA and LA are initially converted to their long-chain metabolites (EPA and AA, respectively) through the same desaturation/elongation pathway; therefore, there exists potential competition between these two families of fatty acids for desaturases and elongases. The initial conversion of ALA to stearidonic acid $(18: 4 n-3)$ is the rate limiting reaction of the pathway. The affinity of delta 6-desaturase for ALA is greater than for LA [58]. As a result, a higher intake of ALA reduces the synthesis of AA from LA and thus, less AA is available for synthesis of inflammatory eicosanoids [59]. Secondly, increase consumption of $n-3$ PUFA results in their incorporation into membrane phospholipids, where they partially replace AA, therefore reducing the substrate for AA derived eicosanoids. Healy et al. showed that dietary supplements with four different concentrations of fish oil resulted in the incorporation of EPA and DHA into human inflammatory cells occurs in a dose-response fashion at the expense of AA [60]. Thirdly, both AA and EPA are substrate for eicosanoid synthesis such as prostaglandins (PG) and leukotrienes (LT) [31]. AA can be metabolized by two major pathways including the cyclooxyenase $(\mathrm{COX})$ and lipoxygenase (LOX) pathways. COX-2 catalyzes the rate limiting step in the formation of 2-series PGs. 5-LOX catalyzes the first step in oxygenation of AA to produce hydroxyl derivatives and 4-series LTs. The overexpression of COX-2 has been detected in many types of cancers and $\mathrm{PGE}_{2}$ has been shown to promote cell proliferation in mammary tumor tissues [61]. PGE2 stimulates the expression and activation of aromatase, the enzyme that converts androgens to estrogens [62]. Therefore, it is hypothesized that estrogen levels can be lowered by decreasing $n-6$ PUFA intake. In contrast, EPA metabolism results in 3-series PGs and 5-series LTs, with a slightly different structure and anti-tumorigenic properties [58]. $n$-3 PUFA supplementation has been shown to lower production of $\mathrm{PGE}_{2}$ (by 60\%) and $\mathrm{LTB}_{4}$ (by 75\%) in human peripheral blood mononuclear cells [63]. Furthermore, 
$n$-3 PUFA has been suggested to suppress the expression of COX-2 and 5-LOX. Feeding mice with high n-3 PUFA diets influences mammary tumor development by down-regulating COX-2 and 5-LOX expression [20,64]. In addition to the inhibitory effects on the generation of inflammatory eicosanoids, recent studies have identified a novel group of lipid mediators, termed resolvins, which are formed from EPA and DHA $[65,66]$. These mediators appear to exert potent anti-inflammatory actions and are considered as potential therapeutic interventions for some chronic inflammatory diseases and cancer $[67,68]$.

Figure 1. Synthetic pathways of long-chain PUFA and eicosanoids. $\alpha$-linolenic acid (ALA; 18:3n-3) and linoleic acid (LA; 18:2n-6) are essential PUFA obtained from the diet, and involve in similar sequential desaturation and elongation steps, give rise to long chain, more unsaturated PUFA eicosapentaenoic acid (EPA; 20:5n-3), docosahexaenoic acid (DHA; 22:6n-3), and arachidonic acid (AA; 20:4n-6). Relevant intermediates in these pathways include SDA (stearidonic acid), ETA (eicosatetraenoic acid), DPA (docosapentaenoic acid), GLA ( $\gamma$-linolenic acid), DGLA (dihomo- $\gamma$-linolenic acid) and AdA (adrenic acid). Both AA and EPA are substrates for the synthesis of eicosanoid products such as prostaglandins (PG) and leukotrienes (LT). The products of $n$ - 6 PUFA tend to promote cell proliferation while the products of $n-3$ PUFA have anti-tumorigenic properties. $n-3$ PUFA may lower the risk of BC by disrupting the biosynthesis of AA-derived inflammatory eicosanoids.

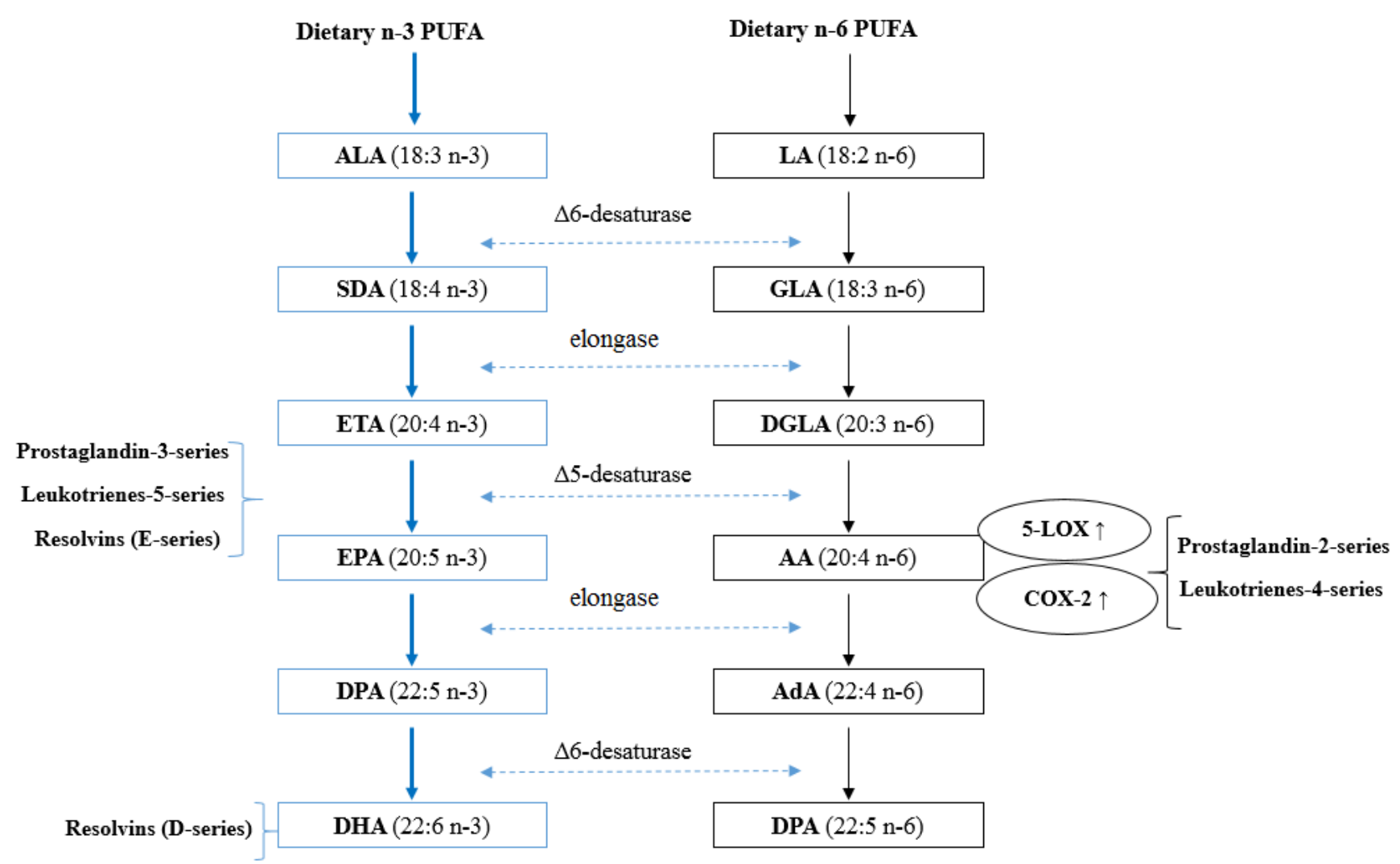

In general, $n$-3 PUFA can not only block AA metabolism, but can also compete with AA for eicosanoid synthesis. This anti-inflammatory effect of $n-3$ PUFA is of interest since chronic inflammation has been linked to cancer initiation and progression [69]. 


\subsection{Influence on Gene Expression, Transcription Factor Activity and Signal Transduction}

$\mathrm{BC}$ development is a multi-step process that requires the accumulation of several genetic alterations in a single cell. Many studies have now demonstrated that the regulation of intracellular signaling is a critical aspect of controlling cell functions in various types of cancers. Neoplastic growth and progression are generally regarded as dependent on a high rate of cell proliferation and a low rate of apoptosis. Dietary PUFA and their metabolites may exert some of their anti-cancer or tumor-promoting effects by affecting gene expression or activating signal transduction molecules involved in the control of cell proliferation, differentiation apoptosis and metastasis (Figure 2).

Figure 2. Hypothetical scheme showing how $n$-3 PUFA modulates cell functions via intracellular signaling molecules. Cell proliferation and cell apoptosis are the two important fundamental processes integral to carcinogenesis. n-3 PUFA exerts anti-cancer effects by reducing the expression of some growth factors including human epidermal growth factor receptor-2 (HER-2), epidermal growth factor receptor (EGFR) and insulin-like growth factor 1(IGF-1R); inhibiting cell proliferation by either activating PPAR $\gamma$ or decreasing levels of fatty acid synthase (FAS) protein; and promoting cell apoptosis via blocking PI3K/Akt pathways, downregulating phosphorylated Akt, inhibiting NF- $\kappa \mathrm{B}$ activity and lowering Bcl-2/Bax ratio.

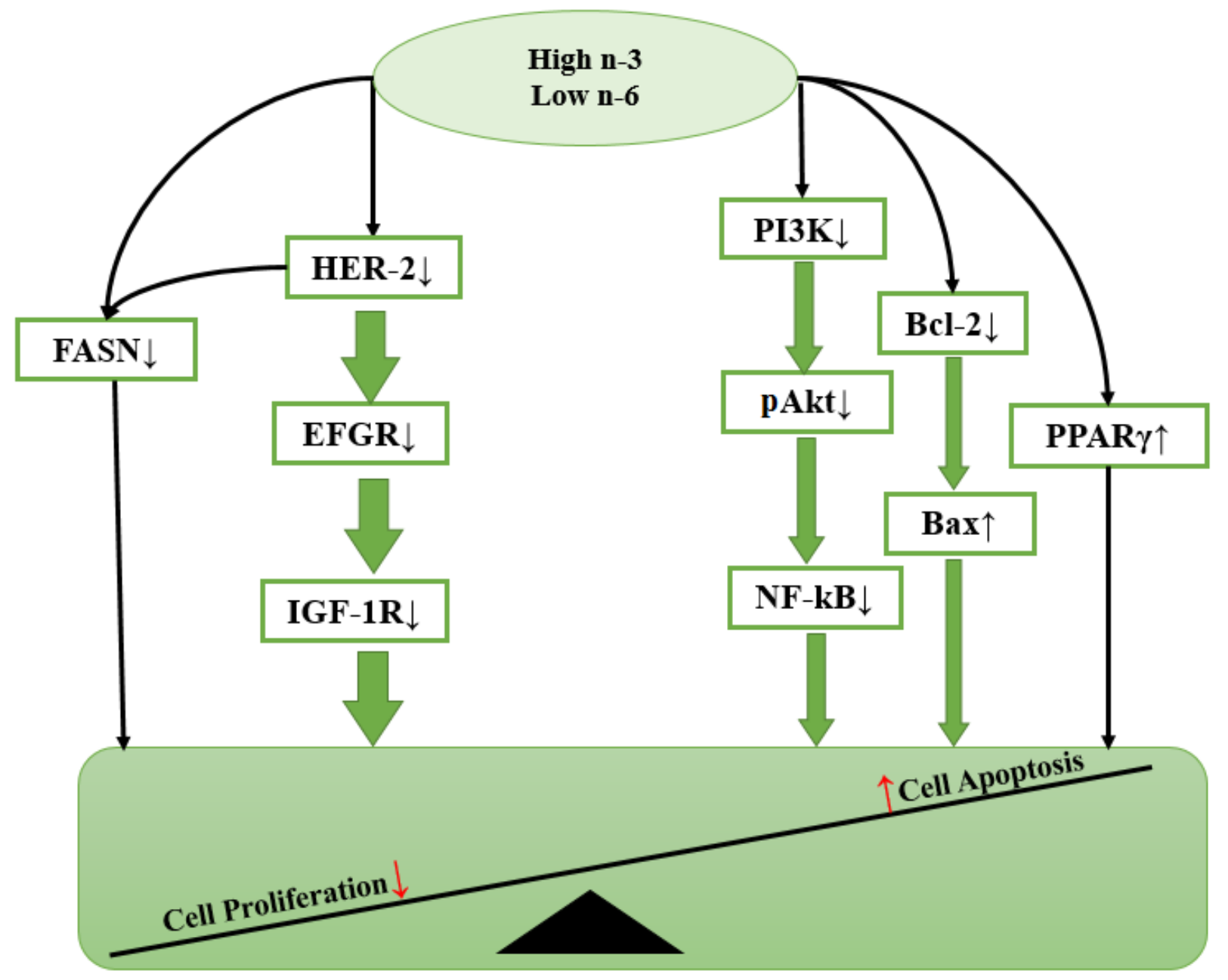




\subsubsection{EGFR and HER-2}

Among numerous factors, carcinogenesis involves the activation of oncogenes such as the epidermal growth factor receptor (EGFR) and human epidermal growth factor receptor-2 (HER-2). EGFR is a receptor tyrosine kinase, which plays essential roles in regulating a number of cellular processes including cell proliferation, survival and migration [70]. EGFR is usually activated in response to extracellular ligands (epidermal growth factor [EGF)) by its phosphorylation [71]. Dysregulated EGFR activation is often associated with overexpression of EGFR, which has been observed in several cancer types including breast carcinomas [72]. Marine n-3 PUFA were able to inhibit EGFR activity, in particular, DHA was found to induce apoptosis in BC cells by down-regulating EGFR expression [71]. Similar to EGFR, HER-2 (HER-2/neu or erbB-2) is a $185-\mathrm{kD}$ transmembrane receptor tyrosine kinase that is involved in human mammary oncogenesis [73]. The overexpression of HER-2 occurs in $25 \%-30 \%$ of human invasive BCs, and is associated with a more aggressive phenotype and poor patient prognosis [12,74]. HER-2 functions as a co-receptor and forms homodimers or heterodimers with EGFR or insulin-like growth factor (IGF-1R) to activate downstream target signaling cascades that involve cell survival and proliferation, such as phosphatidylinositol 3-kinase (PI3K)/Akt, mitogen-activated protein kinase (MAPK) and inhibition of apoptotic pathways such as Bcl-2-associated death promoter protein $[75,76]$. It should be noted that the HER-2 receptors also activate lipogenic pathways mediated by the fatty acid synthase (FAS) protein [6], a key lipogenic enzyme catalyzing the terminal steps in the de novo biogenesis of fatty acids in cancer pathogenesis [51]. Dietary $n$-3 PUFA were demonstrated to inhibit the early stages of HER-2/neu-mediated mammary carcinogenesis in rats [77]. Notably, ALA alone was able to reduce HER-2 protein expression by 79\% in MCF-7 cell lines [78]. Both EGFR and HER-2 are regarded as important therapeutic targets against BC, and $n$-3 PUFA may be a dietary treatment for controlling the growth factor-mediated oncogenesis.

\subsubsection{Peroxisome Proliferator-Activated Receptor Gamma (PPAR $\gamma$ )}

Peroxisome proliferator-activated receptors (PPARs) are members of the nuclear receptor superfamily and function as ligand-activated transcription factors [79]. PPAR $\gamma$ is a subset of the PPAR family, it is mainly expressed in adipose tissue, mammary gland, colon and the immune system [80,81]. PPAR $\gamma$ regulates the expression of target genes by binding to DNA sequence elements, termed PPAR response elements (PPREs). PPREs have been identified in the regulatory regions of a variety of genes that are involved in lipid metabolism and homeostasis, but recently have appeared to be involved in cell proliferation, cell differentiation, and inflammatory responses [79,82]. PPAR $\gamma$ ligands include naturally occurring compounds such as PUFA and eicosanoids, as well as synthetic activators, such as the hypolipidemic drugs [83]. Clay et al. indicated that induction of apoptosis is a biological response resulting from PPAR $\gamma$ activation in some BC cells [84]. $n$-3 PUFA are direct agonists for PPAR $\gamma$, which have been shown to exert anti-tumorigenic effects via the activation of PPAR $\gamma[82,85]$. For instance, DHA was found to attenuate MCF-7 cell proliferation by activation of PPAR $\gamma$ [86]. In addition, dietary supplementation with a low ratio of $n-6 / n-3$ PUFA (1:14.6) was shown to increase PPAR $\gamma$ protein content, which was paralleled with a reduction of tumor burden in rats with induced mammary 
carcinogenesis [87]. As a result, PPAR $\gamma$ activation is beneficial for controlling BC, which suggests a potential role for PPAR $\gamma$ ligands in the treatment of BC.

\subsection{3. $\mathrm{Bax} / \mathrm{Bcl}-2$}

Apoptosis is a form of cell death triggered during a variety of physiological conditions and is tightly regulated by a number of gene products that promote or block cell death at different stages [88]. Bcl-2 is well-known as an important apoptosis-regulator protein [89], normally blocking apoptosis and its overexpression contributes to BC by prolonging cell survival [90]. Bax is a pro-apoptotic member of the Bcl-2 family of proteins. It is likely to have pore-forming activity to increase mitochondrial membrane permeability, and can also form a homodimer with Bcl-2 to enhance the effects of apoptotic stimuli $[90,91]$. Raisova et al. showed that the Bax/Bcl-2 ratio determines the susceptibility of cells to apoptosis [92]. Thus, a low Bax/Bcl-2 ratio is associated with enhanced survival of BC cells and resistance to apoptosis, and vice versa. It has been proposed that diets rich in $n$-3 PUFA, such as fish and canola oil, reduces the abundance of Bcl-2 and up-regulates Bax expression to induce apoptosis, thereby reducing $\mathrm{BC}$ risk [27,93].

\subsubsection{PI3K/Akt, NF-kB}

Besides Bcl-2, the PI3K/Akt pathway also plays an important role in cell apoptosis. Phosphatidylinositol 3-kinase (PI3K) is a heterodimeric lipid kinase that is composed of a regulatory and catalytic subunit that are encoded by different genes [93]. The primary consequence of PI3K activation is the generation of the second messenger PtdIns $(3,4,5)$ P3 (PIP3) in the membrane, which in turn recruits and activates Akt, a downstream serine/threonine kinase [94]. Akt activation is a dual regulatory mechanism that requires translocation to the plasma membrane and phosphorylation at Thr308 and Ser473 [52,94,95]. Due to this mechanism, Akt functions as an anti-apoptotic signaling molecule. Thus, upregulation of phosphorylated Akt is relevant to tumor cell growth and resistance to cell apoptosis $[6,87,96]$. HER-2 overexpression constitutively activates survival and proliferation pathways by increasing activation of Akt, however, $n$-3 PUFA was found to either modulate total Akt expression or interact with Akt to down-regulate its phosphorylation [6,97]. Since Akt requires translocation to the plasma membrane for activation, it is possible that tumor cell membrane enrichment of $n-3$ PUFA might affect the phosphorylation of Akt that are recruited to the membrane for activation [96]. In addition, recent studies have demonstrated that $\mathrm{PI} 3 \mathrm{~K} / \mathrm{Akt}$ promoted cell survival is mediated, in part, through the activation of the nuclear factor kappa-B (NF- $\mathrm{B})$ transcription factor $[95,98,99]$. NF- $\mathrm{B}$ is a key regulator of genes involved in cell proliferation, migration, and angiogenesis [100,101]. In tumor cells, impaired regulation of NF- $\kappa \mathrm{B}$ activation will lead to deregulated expression of the anti-apoptotic genes

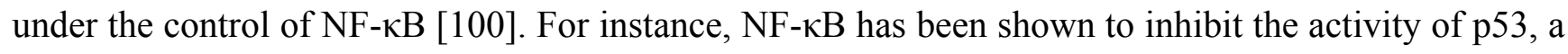
tumor suppressor known to trigger apoptosis in cells with damaged DNA [102]. As a result, constitutive $\mathrm{NF}-\kappa \mathrm{B}$ expression may contribute to the development and progression of $\mathrm{BC}$. 


\subsubsection{Cell Proliferation Marker: Ki-67 and PCNA}

Cell proliferation is another fundamental process integral to carcinogenesis. Ki-67 is a nuclear protein, and being widely used as a prognostic or predictive marker in $\mathrm{BC}$ and other malignant disease [103]. The human Ki-67 protein is present during all active phases of the cell cycle $G(1), S, G(2)$, and mitosis, but is absent from resting cells $\mathrm{G}(0)$, which makes Ki-67 an excellent marker for determining the growth fraction of a given cell population [104]. Ki-67 immunohistochemical staining has been used as an index of tumor growth in numerous of cancer studies, especially prostate and breast carcinomas [26,87]. Treatment with ALA-rich flaxseed oil markedly lowered tumor burden in rats accompanied by reduced Ki-67 level [78,105].

Similarly to Ki-67, Proliferating Cell Nuclear Antigen (PCNA) is also considered a potential prognostic marker in BC [106]. PCNA is a ring-like nuclear protein which functions as the sliding clamp of DNA polymerases [107,108]. Thus, it is involved in DNA replication and repair machinery of the cell [109]. Expression of PCNA is a valid cell proliferation marker since the distribution of PCNA was found to occur during G1, S and G2 phase, but reaches low immunohistochemically detectable levels in M-phase of the cell cycle $[106,108,109]$. It has been shown that supplementation with $n$-3 PUFA reduces the percentage of proliferating tumor cells by decreasing the expression of PCNA [110].

The overall effect of high $n$-3 PUFA intake on cellular signaling process either inhibits cell proliferation or promotes cell apoptosis (Figure 2). The changes in gene expression, transcription factor activity and signaling transduction will be highlighted in the following sections.

\section{The Effect of $\boldsymbol{n - 3}$ PUFA Mixtures on BC Development}

\subsection{Animal Studies}

The inhibitory effects of $n-3$ PUFA on tumor growth have been well documented in rodent models of BC. Xenograft, transgenic and chemically induced methods are the three main approaches employed in rodent models.

\subsubsection{Breast Cancer Studies in Xenograft Rodent Models}

Xenograft rodent models involve the transplantation of human $\mathrm{BC}$ cells into immunocompromised mice $[78,111]$. The type and concentration of dietary PUFA have profound influences on the growth rate of transplantable human BC in rodents (Table 3). In one study, MDA-MB-435 BC cells xenografted into athymic nude mice in order to compare intake of LA alone with diets containing LA and various proportions of EPA/DHA [20]. The diet rich in $n-6$ PUFA stimulated the growth and migration of human BC cells in mice, whereas diets supplemented with EPA or DHA exerted suppressive effects [20]. Similarly, Karmail et al. also found an inhibition of R3230AC mammary tumor growth in rat fed with Maxepa, a menhaden oil supplement that contains approximately 18\% EPA and 12\% DHA [112]. These observations were largely attributed to the high incorporation of $n$-3 PUFA into the tumor phospholipids, which further reduced pro-inflammatory eicosanoid synthesis from AA [20]. More recently, a diet supplemented with $3 \% \mathrm{w} / \mathrm{w}$ fish oil concentrate was shown to stimulate lipid peroxidation in the tumor cells, and thereby slowed down the tumor growth rate in athymic nude mice implanted with 
MDA-MB-231 [30]. Similar effects were observed in MCF-7 human breast cancer xenografts, although a higher percentage of fish oil $(19 \% \mathrm{w} / \mathrm{w})$ was required to decrease tumor volume in the nude mice [113]. These findings supported an earlier study showed that $n-6 / n-3$ PUFA consumed in a low ratio resulted in prolonged tumor latency and reduced tumor growth rate in BALB/cAnN mice [114]. Therefore, diet enriched with $n$-3 PUFA can alter murine mammary tumorigenesis.

\subsubsection{Breast Cancer Studies in Transgenic Rodent Models}

In transgenic mouse models, tumor growth can be initiated in two different ways: gain of function involving oncogenes responsible for cell proliferation or loss of function involving cell apoptotic pathways $[115,116]$. For example, the mouse mammary tumor virus (MMTV) promoter allows the cancer-causing virus to be activated and expressed in mammary tissue, leading to the development of mammary tumors [117]. Several studies have employed MMTV-neu related models and provided strong evidence for protective effects of $n-3$ PUFA towards HER-2 positive BC (Table 4).

One study examined mammary tumor development in MMTV-Her-2/neu mice fed menhaden fish oil from 7 weeks of age onwards. The tumor incidence was dramatically reduced as well as prolonged tumor latency [115]. Further, Yee et al. demonstrated that dietary n-3 PUFA downregulated COX-2 and Ki-67 to inhibit cell proliferation, further reducing atypical hyperplasia to prevent HER-2/neu mammary carcinogenesis at early stages [77]. Moreover, we showed that lifelong $n-3$ PUFA exposure can mitigate tumor development in mice expressing MMTV-neu(ndl)-YD5, a more aggressive HER-2- positive BC model [116]. In this study, MMTV-neu(ndl)-YD5 mice were crossed with fat-1 mice, yielding mice that were capable of endogenous synthesis of $n-3$ from $n-6$ PUFA and had the susceptibility to mammary tumor growth [116]. Thus, this study provided a direct evidence for a protective effect of $n-3$ PUFA via both complementary genetic and conventional dietary approaches [116]. In order to understand the dose-dependent effect of $n$-3 PUFA on mammary gland tumor development, Leslie et al. further demonstrated a dose-response relationship of $0 \%, 3 \%$ and $9 \%(\mathrm{w} / \mathrm{w})$ menhaden oil on tumor burden reduction in MMTV-neu-YD5 mice [21]. In line with the previous study, the observed dose-dependent effects of $n$-3 PUFA were associated with a dose-dependent change in the fatty acid profile, reflecting a decreased $n-6 / n-3$ ratio in the mammary glands and an increased of EPA and DHA in tumor phospholipid classes [21]. This is consistent with an earlier human clinical trial which showed dietary DHA and EPA supplementation caused a dose-dependent increase of $n-3$ PUFA in serum and breast adipose tissues of BC patients [118]. 
Table 3. $n$-3 PUFA and breast cancer risk: Xenograft rodent models.

\begin{tabular}{|c|c|c|c|c|c|}
\hline Animal Model & n-3 PUFA Source & Feeding Period & Main Findings & Mechanism & Reference \\
\hline $\begin{array}{l}\text { Athymic nu/nu mice } \\
\text { MDA-MB } 231\end{array}$ & $\begin{array}{c}3 \% \mathrm{w} / \mathrm{w} \text { fish oil concentrate } \\
(10.2 \mathrm{~g} / \mathrm{kg} \text { EPA, } 7.2 \mathrm{~g} / \mathrm{kg} \\
\text { DHA, } 3.0 \mathrm{~g} / \mathrm{kg} \text { ALA })\end{array}$ & $\begin{array}{c}\text { 7-week } \\
\text { (fed after tumor } \\
\text { established) }\end{array}$ & $\begin{array}{c}\downarrow \text { tumor growth rate } \\
\uparrow \text { effectiveness of doxorubucin }\end{array}$ & $\begin{array}{l}\uparrow \text { EPA incorporation into tumor } \\
\uparrow \text { lipid peroxidation in tumor }\end{array}$ & {$[30]$} \\
\hline $\begin{array}{l}\text { Athymic nu/nu mice }(\mathrm{NCr}-\mathrm{nu} / \mathrm{nu}) \\
\text { MDA-MB } 435\end{array}$ & 40 or $80 \mathrm{~g} / \mathrm{kg}$ EPA, DHA & $\begin{array}{c}\text { 13-week } \\
\text { (fed before } \\
\text { transplantation) }\end{array}$ & $\begin{array}{c}\downarrow \text { tumor growth, size } \\
\quad \downarrow \text { tumor weight }\end{array}$ & $\begin{array}{c}\uparrow \text { EPA, DHA in tumor phospholipids } \\
\downarrow \text { LA, AA in tumor phospholipids } \\
\downarrow \text { AA-derived eicosanoids }\end{array}$ & {$[20]$} \\
\hline Inbred F44 rats R3230AC & $\begin{array}{c}5 \% \text { marine oil } \\
\text { supplementation } \\
(18 \% \text { EPA, } 12 \% \text { DHA }) \\
\end{array}$ & $\begin{array}{c}\text { 4-week } \\
\text { (fed before } \\
\text { transplantation) }\end{array}$ & $\downarrow$ tumor weight, volume & $\begin{array}{c}\uparrow \text { EPA, DHA, AA incorporation into tumor } \\
\downarrow \text { Prostaglandins } 2 \text { series }\end{array}$ & [112] \\
\hline $\begin{array}{l}\text { BALB/cAnN mice } \\
\text { Mouse BC cell }\end{array}$ & $\begin{array}{c}10 \% \text { or } 20 \% \mathrm{w} / \mathrm{w} \text { menhaden } \\
\text { fish oil }\end{array}$ & $\begin{array}{c}\text { 7-week } \\
\text { (fed before } \\
\text { transplantation) }\end{array}$ & $\begin{array}{l}\uparrow \text { tumor latency } \\
\downarrow \text { tumor growth rate }\end{array}$ & NA & [114] \\
\hline $\begin{array}{l}\text { Athymic nude mice } \\
\qquad \text { MCF-7 }\end{array}$ & $\begin{array}{c}19 \% \mathrm{w} / \mathrm{w} \text { menhaden oil } \\
(1.9 \mathrm{~g} / \mathrm{kg} \text { ALA, } 19.4 \mathrm{~g} / \mathrm{kg} \\
\text { EPA, } 24.3 \mathrm{~g} / \mathrm{kg} \text { DHA })\end{array}$ & $\begin{array}{c}6 \text { or } 8 \text {-week } \\
\text { (fed after tumor } \\
\text { established) }\end{array}$ & $\downarrow$ tumor volume & $\uparrow$ lipid peroxidation in tumor & [113] \\
\hline
\end{tabular}

$\uparrow$ : increase; $\downarrow$ : decrease; NA: not available. 
Table 4. n-3 PUFA and breast cancer risk: transgenic rodent models.

\begin{tabular}{|c|c|c|c|c|c|}
\hline Animal Model & n-3 PUFA Source & Feeding Period & Main Findings & Mechanism & Reference \\
\hline MMTV-HER-2/neu & $\begin{array}{c}22.50 \mathrm{kcal} \% \text { menhaden oil } \\
(15 \mathrm{~g} / \mathrm{kg} \text { EPA, } 10.8 \mathrm{~g} / \mathrm{kg} \text { DHA })\end{array}$ & $\begin{array}{l}\text { 28-week } \\
\text { (fed before tumor } \\
\text { development) }\end{array}$ & $\begin{array}{c}\downarrow \text { atypical ductal hyperplasia } \\
\quad \downarrow \text { cell proliferation } \\
\text { prevented HER-2/neu at early stages }\end{array}$ & $\begin{array}{l}\downarrow \mathrm{Ki}-67 \text { expression } \\
\downarrow \text { COX-2 expression }\end{array}$ & {$[77]$} \\
\hline MMTV-HER-2/neu & $\begin{array}{c}22.50 \mathrm{kcal} \% \text { menhaden oil } \\
(15 \mathrm{~g} / \mathrm{kg} \text { EPA, } 10.8 \mathrm{~g} / \mathrm{kg} \text { DHA })\end{array}$ & $\begin{array}{l}\text { 52-week } \\
\text { (fed before tumor } \\
\text { development) }\end{array}$ & $\begin{array}{l}\downarrow \text { tumor incidence and multiplicity } \\
\qquad \uparrow \text { tumor latency } \\
\quad \downarrow \text { mammary gland dysplasia }\end{array}$ & NA & [115] \\
\hline $\begin{array}{c}\text { MMTV-neu } \\
(\text { ndl)-YD5 } \times \text { fat1 }\end{array}$ & $\begin{array}{c}3 \% \mathrm{w} / \mathrm{w} \text { menhaden oil ( } 0.5 \mathrm{~g} / \mathrm{kg} \\
\text { ALA, } 4.1 \mathrm{~g} / \mathrm{kg} \text { EPA, } 3 \mathrm{~g} / \mathrm{kg} \text { DHA })\end{array}$ & $\begin{array}{l}20 \text {-week } \\
\text { (lifelong treatment, } \\
\text { fed before tumor } \\
\text { development) }\end{array}$ & $\downarrow$ tumor volume and multiplicity & $\begin{array}{c}\uparrow \text { EPA, DHA and overall } n-3 \text { in } \\
\text { mammary tissues } \\
\downarrow n-6 / n-3 \text { ratio in tumor } \\
\text { phospholipids } \\
\end{array}$ & [116] \\
\hline MMTV-neu (ndl)-YD5 & $\begin{array}{c}3 \% \mathrm{w} / \mathrm{w} \text { menhaden oil }(0.5 \mathrm{~g} / \mathrm{kg} \\
\text { ALA, } 4.1 \mathrm{~g} / \mathrm{kg} \text { EPA, } 3 \mathrm{~g} / \mathrm{kg} \text { DHA }) \\
9 \% \mathrm{w} / \mathrm{w} \text { menhaden oil }(1.3 \mathrm{~g} / \mathrm{kg} \\
\text { ALA, } 12.4 \mathrm{~g} / \mathrm{kg} \text { EPA, } 9 \mathrm{~g} / \mathrm{kg} \text { DHA })\end{array}$ & $\begin{array}{l}20 \text {-week } \\
\text { (lifelong treatment, } \\
\text { fed before tumor } \\
\text { development) }\end{array}$ & $\begin{array}{l}\downarrow \text { tumor volume and multiplicity } \\
\qquad \uparrow \text { tumor latency } \\
\text { (all in a dose-dependent manner) }\end{array}$ & $\begin{array}{c}\uparrow \text { EPA, DPA in mammary tissues } \\
\uparrow \text { EPA, DHA in tumor } \\
\text { phospholipids } \\
\downarrow \text { LA, AA, } n-6 / n-3 \text { PUFA ratio in } \\
\text { both mammary and tumor tissues in } \\
\text { a dose-dependent manner }\end{array}$ & {$[21]$} \\
\hline
\end{tabular}


Supplementing mice with $24 \%(\mathrm{w} / \mathrm{w})$ menhaden oil delayed mammary tumor development by 15 weeks relative to mice fed the same amount of corn oil [119]. This result heightened the potential value of $n-3$ as an effective agent against BC, while the timing of exposure to $n$-3 PUFA will also influence future cancer risk [34]. Mammary gland research has identified critical periods of development, including early windows such as in utero, lactation and pubescence. The mammary gland undergoes rapid growth during these periods, and exposure to environmental agents may influence the long-term health of mammary tissue. Thus, supplement with $n$-3 PUFA in early life stages may protect against later $\mathrm{BC}$ development. In support of this, $\mathrm{Su}$ et al. conducted a study exposing rats to maternal high $n$-6 PUFA diet with or without fish oil supplementation during the perinatal period via maternal intake or during puberty or adulthood [29]. They found that fish oil intake during the perinatal period had a greater effect in preventing mammary tumors than fish oil supplementation in later life [29]. The decreased maternal serum estradiol levels in pregnant rats with fish oil supplementation was thought to play a role in reducing susceptibility to later BC development in the female offspring [29].

\subsubsection{Breast Cancer Studies in Chemically-Induced Rodent Models}

Evidence from chemical-induced BC studies consistently supports the anti-cancer effect of $n$-3 PUFA. Induced mammary carcinoma in rats by the injection of carcinogenic chemicals such as 7 , 12-dimethylbenz $(\alpha)$ anthracene (DMBA) and $N$-methyl- $N$-nitrosourea (MNU) have been widely used in various BC chemopreventive studies. When provided in the diet through menhaden or fish oil concentrates, the incorporated $n$-3 PUFA, EPA and DHA in particular, lower tumor incidence as well as retard tumor growth and metastasis of chemically-induced and transplantable mammary tumors (Table 5). Olivo et al. compared the effects of low- or high-, $n-3$ or $n$-6 PUFA exposure on mammary tumorigenesis in rats [110]. Feeding rats a low-fat $n-3$ diet significantly lowered the incidence of DMBA-induced mammary tumors compared to $n-6$ fed rats. This was accompanied by reduced cell proliferation and elevated lipid peroxidation. However, the high-fat $n-3$ diet resulted in a significant increase risk of mammary tumorigenesis relative to rats fed with $n-6$ diets [110]. Further, an in vivo study demonstrated that low-fat $n-3$ PUFA diets inhibited cell proliferation via activation of PPAR $\gamma$ and/or down-regulation of COX-2 and PCNA expression; whereas high fat $n-3$ PUFA diets stimulated cell proliferation and were positively associated with levels of phosphorylated Akt [110]. Similar suppressive effects of $n-3$ PUFA were observed in another DMBA-induced rat model [27]. Supplementation of EPA and DHA (from Maxepa) effectively suppressed cell proliferation, which was accompanied by down-regulation of Ki-67 and HER-2/neu positive expressions. Meanwhile, EPA and DHA induced cell apoptosis through modulating the expression of Bcl-2 and Bax in mammary tissue of Sprague-Sawley rats [26-28]. These findings suggest that gene-nutrient interactions are of a critical importance in the development of $\mathrm{BC}$. 
Table 5. $n$-3 PUFA and breast cancer risk: Chemically-induced rodent models.

\begin{tabular}{|c|c|c|c|c|c|}
\hline Carcinogen & n-3 PUFA Source & Feeding Period & Main Findings & Mechanism & Reference \\
\hline MNU & $\begin{array}{l}\text { Fish oil } 2 \%-10 \% \mathrm{w} / \mathrm{w} \\
n-3 \text { PUFA in diet }\end{array}$ & $\begin{array}{l}\text { 18-week (at the same time as } \\
\text { MNU administration) }\end{array}$ & $\begin{array}{c}\text { Absolute } n \text {-3 diet: } \\
\downarrow \text { body weight, no tumor occurrence } \\
(10 \% \text { w/w } n-3 \text { PUFA) } 1: 1 n-6 / n-3 \text { diet } \\
\downarrow \text { tumor incidence and multiplicity } \\
(5 \% \mathrm{w} / \mathrm{w} n-3 \text { PUFA })\end{array}$ & $\begin{array}{c}\uparrow \text { EPA, DHA in } \\
\text { mammary } \\
\downarrow \text { FAS, COX-2, } \\
5-\text { LOX }\end{array}$ & [64] \\
\hline MNU & $\begin{array}{c}\text { Fish oil concentrate } \\
\text { Low } n-6 / n-3=1: 14.6 \\
\text { High } n-6 / n-3=1: 0.7\end{array}$ & $\begin{array}{l}\text { 2-week (at the same time as } \\
\text { MNU administration) }\end{array}$ & $\begin{array}{c}\text { Low } v s \text {. high ratio } n \text { - } 6 / n-3 \text { PUFA diet: } \\
\downarrow \text { tumor incidence }(21 \%), \\
\downarrow \text { tumor multiplicity (30\%), tumor } \\
\text { burden }(80 \%) \\
\uparrow \text { apoptotic index }(129 \%)\end{array}$ & $\begin{array}{c}\downarrow \mathrm{Ki}-67 \\
\uparrow \mathrm{Bax}, \mathrm{Bax} / \mathrm{Bcl} 2, \\
\mathrm{PPAR} \gamma \\
\downarrow \mathrm{NF}-\kappa \mathrm{B} \text { p65, } \\
\text { pAkt, IGF-IR }\end{array}$ & [87] \\
\hline $\mathrm{MNU}$ & $\begin{array}{l}\text { EPA/DHA alone: } 95 \mathrm{~g} / \mathrm{kg} \text { EPA/DHA EPA } \\
+ \text { DHA: } 47.5 \mathrm{~g} / \mathrm{kg} \text { EPA + } 47.5 \mathrm{~g} / \mathrm{kg} \text { DHA }\end{array}$ & $\begin{array}{l}\text { 20-week (at the same time as } \\
\text { MNU administration) }\end{array}$ & $\begin{array}{l}\text { DHA alone } v s \text { EPA + DHA vs EPA } \\
\text { alone: } \\
\downarrow \text { tumor incidence: } 23 \%, 73 \%, 65 \% \\
\downarrow \text { tumor multiplicity: } 0.23,1.67,1.59 \\
\text { DHA is more effectively than EPA }\end{array}$ & NA & {$[120]$} \\
\hline DMBA & $\begin{array}{c}\text { Maxepa (fish oil concentrate): } \\
90 \mathrm{mg} \text { EPA + } 60 \text { mg DHA per day }\end{array}$ & $\begin{array}{l}\text { 24-week study } 35 \text {-week study } \\
\text { (before DMBA injection) }\end{array}$ & $\begin{array}{c}\downarrow \text { DNA single-strand breaks } \\
\downarrow \text { cell proliferation }\end{array}$ & $\begin{array}{l}\downarrow \text { Ki-67, Her- } \\
2 / \text { neu }\end{array}$ & [26] \\
\hline
\end{tabular}


Table 5. Cont

\begin{tabular}{|c|c|c|c|c|c|}
\hline DMBA & $\begin{array}{c}\text { Maxepa: } 90 \text { mg EPA + } 60 \text { mg DHA per } \\
\text { day }\end{array}$ & $\begin{array}{c}\text { 24-week study } \\
\text { 35-week study } \\
\text { (before DMBA injection) }\end{array}$ & $\begin{array}{c}\downarrow \text { tumor incidence }(23 \%) \text {, tumor } \\
\text { multiplicity }(42 \%) \\
\uparrow \text { cell apoptosis } \downarrow \text { cell proliferation }\end{array}$ & $\begin{array}{c}\downarrow \mathrm{Bcl}-2 \uparrow \mathrm{Bax} \\
\uparrow \mathrm{p} 53\end{array}$ & {$[27,28]$} \\
\hline DMBA & $\begin{array}{c}\text { Fish oil }(0.5 \% \text { ALA, } 16 \% \text { EPA, } 1.2 \% \\
\text { DPA, } 8 \% \text { DHA in fish oil })\end{array}$ & NA & $\begin{array}{c}\downarrow \text { tumor incidence with fish oil } \\
\text { consumption: adulthood }<\text { in utero }< \\
\text { puberty }<\text { perinatal } \\
\downarrow \text { tumor multiplicity with fish oil } \\
\text { consumption: adulthood }>\text { puberty }> \\
\text { perinatal }>\text { in utero }\end{array}$ & $\begin{array}{l}\downarrow \text { maternal serum } \\
\quad \text { estradiol }\end{array}$ & [29] \\
\hline DMBA & $\begin{array}{c}\text { Menhaden oil Low-fat } n-3 \text { PUFA diet: } 4.6 \\
\text { g/kg EPA }+3.2 \text { g/kg DHA High fat } n-3 \\
\text { PUFA diet: } \\
9.1 \mathrm{~g} / \mathrm{kg} \text { EPA }+6.3 \mathrm{~g} / \mathrm{kg} \text { DHA }\end{array}$ & $\begin{array}{l}\text { 20-day (before } \\
\text { DMBA injection) }\end{array}$ & $\begin{array}{c}\text { Low } n \text {-3 diet: } \\
\downarrow \text { tumor incidence } \downarrow \text { TEBs } \\
\downarrow \text { cell proliferation } \\
\uparrow \text { cell apoptosis; } \\
\text { High } n \text {-3 diets exert opposite effects }\end{array}$ & $\begin{array}{c}\text { Low } n-3 \text { diet: } \\
\downarrow \text { COX-2, PCNA } \\
\uparrow \text { PPAR } \gamma \\
\uparrow \text { lipid } \\
\text { peroxidation } \\
\text { High } n-3 \text { diet: } \\
\uparrow \text { pAkt } \uparrow \text { lipid } \\
\text { peroxidation }\end{array}$ & {$[110]$} \\
\hline
\end{tabular}

$\uparrow$ : increase; $\downarrow$ : decrease; NA: not available. 
It has been shown that the different dietary fatty acid composition and $n-6 / n-3$ PUFA ratios can diversely influence the occurrence and progression of $\mathrm{BC}[8,32,64]$. Wei et al. fed MNU-induced rats with various $n-6 / n-3$ PUFA ratios and demonstrated the $1: 1$ ratio of $n-6 / n-3$ PUFA in diet was more effective in the prevention of mammary tumor development when compared with diets higher in $n-6$ PUFA [64]. Replacement of $n-6$ by $n-3$ PUFA in diets, reflected an increase in EPA and DHA in mammary tumor tissue, which subsequently downregulated the expression of lipid metabolic-related genes and inhibited cell proliferation [64]. In agreement with this study, Jiang et al. reported that low $n$-6/n-3 PUFA ratio $(1: 14.6)$ caused $80 \%$ reduction in tumor burden and $30 \%$ decrease in tumor multiplicity in the same rodent model compared to a high $n-6 / n-3$ PUFA ratio (1:0.7). These

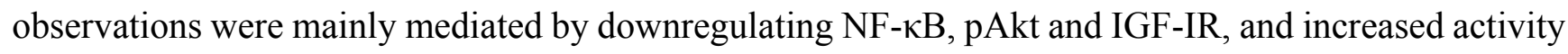
of PPAR $\gamma$ [87].

\subsection{Cell Culture Studies}

It has been well established that $n$-3 PUFA can suppress the development of cancers by inhibiting cellular proliferation and inducing apoptosis. Cell culture studies investigating the effects of $n-3$ PUFA on murine and human $\mathrm{BC}$ cells provide important insights into the mechanisms underlying this inhibitory effect. Although there are few studies describing the individual effects of ALA, EPA and DHA in vitro, the available data consistently show that $n$-3 PUFA have direct growth inhibitory effects on several BC cells lines (Table 6).

MDA-MB-231 human BC cell line was used to investigate the effect of various classes of fatty acids (n-3, $n-6$ and $n$-9 PUFA) [121]. EPA and DHA exhibited a dose-dependent inhibition of cell growth, whereas LA and oleic acid (OA) stimulated cell growth at very low concentration [121]. Some in vitro studies have not included the essential $n$-6 PUFA (i.e., LA) in the growth medium, which would be present in vivo and is required for mammary tumorgenesis in animals. These studies are not able to explain the tumor growth inhibition by $n-3$ PUFA in the presence of abundant LA. Schley et al. examined the inhibitory effects of $n-3$ PUFA on BC in vitro in the presence or absence of LA [22,96]. It was demonstrated that EPA and DHA induced apoptosis and increased DNA fragmentation in MDA-MB-231 cells when provided in combination with LA. Similar effects were observed in the MCF-7 BC cell line $[71,86,105,122]$. Barascu et al. revealed that EPA and DHA decreased MCF-7 cell growth and increased the fraction of apoptotic cells in a concentration-dependent manner, and particularly, a higher efficiency noted for DHA [86]. Specifically, they demonstrated that $n$-3 PUFA inhibited cell proliferation by lengthening the cell cycle between the G2/M transition [86]. In accordance with this finding, a previous study demonstrated that DHA induced marked G2-M and G1-S arrest of the MCF-7 cells [123]. Furthermore, treatment with EPA and DHA was also shown to induce cell differentiation and increase lipid peroxidation product levels in MCF-7 cells [105,124]. 
Table 6. $n$-3 PUFA and breast cancer risk: cell culture studies.

\begin{tabular}{|c|c|c|c|c|}
\hline Cell Type & n-3 PUFA Source & Main Finding & Mechanism & Reference \\
\hline MDA-MB-231 & $\begin{array}{c}\text { EPA/DHA alone: } 75 \mu \mathrm{M} \text { or } 100 \mu \mathrm{M} \text { EPA }+ \text { DHA } \\
\text { combination: } 45 \mu \mathrm{M} \text { EPA }+30 \mu \mathrm{M} \text { DHA or } 60 \mu \mathrm{M} \\
\mathrm{EPA}+40 \mu \mathrm{M} \text { DHA (in presence/absence of LA) }\end{array}$ & $\begin{array}{l}\downarrow \text { cell viability, cell proliferation } \uparrow \text { DNA fragmentation, } \\
\text { cell apoptosis DHA was more potent than EPA }\end{array}$ & $\begin{array}{c}\downarrow \text { pAkt } \downarrow \text { NF- } \kappa \mathrm{B} \text { and DNA } \\
\text { binding activity }\end{array}$ & {$[96]$} \\
\hline MDA-MB-231 & $\begin{array}{c}0.5-2.5 \mu \mathrm{g} / \mathrm{mL} \text { of EPA, DHA } \\
(1.7-8.2 \mu \mathrm{M} \text { EPA, } 1.5-7.6 \mu \mathrm{MDHA})\end{array}$ & $\downarrow$ tumor cells growth $(\mathrm{DHA}>\mathrm{EPA}$, dose-dependent) & $\begin{array}{c}\downarrow \text { LA composition in cell lipids } \\
\downarrow \text { AA-derived eicosanoid } \\
\text { synthesis }\end{array}$ & {$[121]$} \\
\hline MDA-MB-231 & $\begin{array}{c}\text { EPA/DHA alone: } 75 \mu \mathrm{M} \text { or } 100 \mu \mathrm{M} \text { EPA }+ \text { DHA } \\
\text { combination: } 45 \mu \mathrm{M} \text { EPA }+30 \mu \mathrm{M} \text { DHA or } 60 \mu \mathrm{M} \\
\text { EPA }+40 \mu \mathrm{M} \text { DHA (in presence/absence of LA) }\end{array}$ & $\downarrow$ cell growth $(48 \%-62 \%)$ & $\begin{array}{l}\uparrow \text { EPA, DHA, DPA and total } n-3 \text { in } \\
\text { lipid rafts } \downarrow \text { EGFR levels } \uparrow \text { pEGFR }\end{array}$ & {$[22]$} \\
\hline $\begin{array}{l}\text { MDA-MB-231 } \\
\qquad \text { MCF-7 }\end{array}$ & EPA $(230 \mu \mathrm{M})$, DHA $(200 \mu \mathrm{M})$ & $\downarrow$ cell viability $\uparrow$ cell apoptosis & $\begin{array}{c}\downarrow \text { Bcl- } 2 \uparrow \text { pro-caspase- } 8 \downarrow \text { pEGFR } \\
\downarrow \text { EGFR (only DHA) } \downarrow \text { AA } \uparrow \text { EPA, } \\
\text { DPA, DHA in total cell lipids }\end{array}$ & [71] \\
\hline $\begin{array}{l}\text { MDA-MB-231 } \\
\text { MCF-7 }\end{array}$ & $3-100 \mu \mathrm{M}$ of EPA, DHA & $\begin{array}{c}\text { At } 50 \mu \mathrm{M} \text { EPA, } 30 \mu \mathrm{M} \text { DHA } \\
\uparrow \text { cell apoptosis } \\
\downarrow \text { cell growth At } 50 \mu \mathrm{M} \text { EPA, DHA } \\
\uparrow \mathrm{G} 2 / \mathrm{M} \text { duration DHA was more potent than EPA }\end{array}$ & $\begin{array}{l}\downarrow \text { phosphorylation of cyclin B1 } \\
\downarrow \text { activity of CDK1-cyclin B1 }\end{array}$ & {$[86]$} \\
\hline MCF-7 & $100 \mu \mathrm{M}$ of EPA, DHA & $\begin{array}{c}\downarrow \text { cell growth ( } 30 \% \text { by EPA, } 54 \% \text { by DHA) } \\
\uparrow \text { cell differentiation ( } 30 \% \text { by EPA, } 65 \% \text { by DHA) } \\
\text { No significant effects on cell apoptosis and cell cycle } \\
\text { DHA was more potent than EPA }\end{array}$ & $\uparrow \operatorname{PPAR} \gamma$ (DHA only) & {$[125]$} \\
\hline $\begin{array}{l}\text { MCF-7 } \\
\text { MCF-10A }\end{array}$ & 6-30 $\mu \mathrm{M}$ of ALA, EPA, DHA & $\begin{array}{c}\text { All } n \text {-3 PUFA } \downarrow \text { MCF-7 cell growth (EPA, } \\
\text { DHA }>\text { ALA, dose-dependent) AA } \downarrow \text { MCF-7 cell } \\
\text { growth (similar as ALA) }\end{array}$ & NA & [122] \\
\hline $\begin{array}{l}\text { ER+ and } \\
\text { ER- cells }\end{array}$ & $\begin{array}{c}20 \mu \mathrm{g} / \mathrm{mL} \text { of ALA, EPA, DHA (72 } \mu \mathrm{M} \text { ALA, } \\
66 \mu \mathrm{M} \text { EPA, } 61 \mu \mathrm{M} \text { DHA })\end{array}$ & $\begin{array}{c}\text { EPA, DHA } \\
\downarrow \text { cell proliferation (all cell lines) ALA } \\
\downarrow \text { estrogen independent BC cell proliferation }\end{array}$ & $\uparrow$ lipid peroxidation & [124] \\
\hline
\end{tabular}


Chajes et al. examined the effect of ALA, EPA, and DHA on the proliferation of human estrogen-positive $(\mathrm{ER}+)$ and estrogen-negative (ER-) BC cell lines [124]. EPA and DHA displayed a significant inhibitory effect on the proliferation of all types of tumor cells, whereas ALA significantly inhibited cell growth in (ER-) MDA-MB-231 and HBL-100 human breast tumor cells but not in (ER+) MCF-7 cells [124]. The efficiency of this inhibitory effect was found to be correlated with the generation of lipid peroxidation products [124]. Consistently, another in vitro study identified a dose-dependent inhibitory effect of ALA, EPA, and DHA on MCF-7 cells; however, the cells were dramatically inhibited by EPA and DHA, and moderately inhibited by ALA [122].

Rapid tumor cell proliferation is a critical feature for tumor aggressiveness. Treatment with LA and OA increased MDA-MB-231 cell proliferation through production of pro-inflammatory prostaglandins and leukotrienes [121]. EPA and DHA could mimic the effect of indomethacin, an inhibitor of both COX and LOX, which in turn attenuated BC cell proliferation by inhibiting $n-6$ PUFA related eicosanoid synthesis [126]. In addition, treatment with EPA and DHA inhibited EGFR phosphorylation and diminished EFGR levels in lipid rafts [22,71]. These observations were due to the incorporation of $n-3$ PUFA into BC cell membrane, which subsequently altered membrane structure, signal transduction and function of BC cells [71]. Moreover, $n$-3 PUFA can exert anti-proliferative effects by limiting cell cycle progression, attributed to an inhibition of CDK1-cyclin B1 complex, a master regulator required for the initiation of mitosis [86]. Furthermore, increasing evidence demonstrated that $n$-3 PUFA can inhibit cell proliferation and increase cell differentiation by activating $\operatorname{PPAR} \gamma$, although this effect was only observed with DHA treatment [105].

Dysregulation of apoptosis is also a hallmark of cancer cells, and thus agents that activate apoptosis are highly desired. Treatment with EPA and DHA inhibited phosphorylation of Akt as well as the NF- $\kappa$ B DNA binding activity [96]. This represents a novel mechanism by which $n-3$ PUFA induce apoptosis in MDA-MB-231 cells [96]. Additionally, it has been shown that $n-3$ PUFA decreased expression of Bcl-2 and increased activity of pro-caspase-8, an apoptosis effector enzyme [71]. As a result, $n$-3 PUFA can inhibit BC development in vitro by both suppressing tumor cell proliferation and inducing tumor cell death.

\section{The Effect of Individual $n$-3 PUFA on BC Development}

\subsection{ALA and BC}

\subsubsection{Inefficient Conversion from ALA to EPA and DHA}

$\alpha$-Linolenic acid (18:3n-3; ALA) is the major $n$-3 PUFA in the Western diet. Typical consumption of ALA in Europe, Australia and North America ranges between 0.6 and $1.7 \mathrm{~g}$ per day in men and 0.5-1.4 g per day in women [58]. This is about 10-fold lower than the consumption of $n$ - 6 PUFA. ALA, regarded as the precursor for long-chain PUFA, can be converted to EPA (20:5n-3), DPA $(22: 5 n-3)$ and DHA (22:6n-3) by the pathway shown in Figure 1 . Whether the essentiality of ALA in the diet primarily reflects the activity of ALA itself or of long-chain PUFA synthesized from ALA is a matter of debate. The concentration of ALA in plasma phospholipids, cells and tissues is found to less than $0.5 \%$ of total fatty acids [127]. Although the dietary intake of EPA and DHA are approximately 10 -fold lower than those of ALA in North America, the concentrations of these long-chain PUFA in 
plasma, cell and tissue phospholipids are greater than those of ALA [127]. This apparent mismatch between dietary intakes and levels of incorporation further suggests that the primary biological role of ALA is for EPA and DHA synthesis. However, it is also possible that the low concentration of ALA may be due to negative selection in the incorporation of ALA into blood and cell membrane lipid pools [58]. Since consumption of EPA and DHA show a strong inverse association with the risk of BC, this raises the question of whether conversion of ALA to EPA and DHA in humans is a viable alternative to dietary sources of these long-chain PUFA. The majority of human studies estimate that ALA supplementation in human adults generally lead to an increase in EPA and DPA, but have little or no effect on DHA content [128-132]. Conservatively, Pawlosky et al. estimated the overall efficiency of conversion from ALA was $0.2 \%$ to EPA, $0.13 \%$ to DPA and $0.05 \%$ to DHA [129]. This inefficient conversion is due to the first rate limiting reaction catalyzed by $\Delta 6$-desaturase [58]. As a result, the extent of ALA conversion to EPA and DHA is inefficient and limited. Thus, ALA may not be considered as an effective alternative source to fish for providing EPA and DHA.

\subsubsection{Individual Effect of ALA on Breast Cancer}

Data derived from epidemiological and observational studies suggest that ALA present in the Western diet has protective effects in BC (Tables 7 and 8). Two case control studies compared the fatty acid composition in the adipose breast tissue from women with invasive non-metastatic breast carcinoma and women with benign breast disease [45,133]. Low ALA content in adipose tissue was found to be associated with an increased risk of BC. This observation was consistent with a previous cohort study on $121 \mathrm{BC}$ patients, which demonstrated a link between a low level of ALA in adipose breast tissue and increased risk of metastatic development [134]. In particular, the ratio of $n-6 / n-3$ PUFA was also shown to be positively correlated with $\mathrm{BC}$ in these patients, highlighting the role of $n-3$ and $n-6$ PUFA balance in BC.

Dietary supplementation of ALA reduced the growth of established mammary tumors in chemically-induced rats and xenograft rodent models. In OVX athymic mice with high circulating estrogen level, flaxseed oil and its high ALA content, attenuated (ER+) MCF-7 breast tumor growth by reducing cell proliferation and increasing apoptotic index [78]. This effect was probably due to the downregulation of tyrosine kinase receptors such as EGFR and HER2, with a subsequent reduction in pAkt. Compared to corn oil, consumption of ALA-rich flaxseed oil tends to modify the $n-6 / n-3$ PUFA ratio by increasing serum ALA, EPA and DHA concentrations. This provides evidence that ALA absorption and conversion may contribute to the observed tumor reducing effect in the flaxseed oil diet [78]. Further, an in vitro study showed that pure ALA inhibited MCF-7 cell proliferation by 33\%, which was in accordance with the in vivo reduction in palpable tumor growth (33\%) [78]. This suggests that ALA itself, rather than the generated EPA and DHA, exerts this anti-tumorigenic effect [78]. Another in vivo study was designed to elucidate which component(s) of flaxseed (lignan or ALA) was responsible for enhancing tamoxifens effect on reducing the growth of established MCF-7 breast tumors at low circulating estrogen levels [105]. ALA-rich flaxseed oil had a stronger effect in reducing the palpable tumor size of tamoxifen-treated tumors compared with lignan-treated mice [105]. More importantly, ALA was found to downregulate HER2 expression, and subsequently modulate growth factor-mediated signaling pathways by repressing IGF-1R and Bcl-2 [105]. 
Table 7. Individual role of ALA, EPA and DHA on BC.

\begin{tabular}{|c|c|c|c|c|}
\hline n-3 PUFA & Amount of Fatty Acid & Effect & Mechanism & Reference \\
\hline \multirow{16}{*}{ ALA } & NA & Moderate decrease $\mathrm{BC}$ risk & NA & {$[45]$} \\
\hline & $\sim 22.8 \mathrm{~g}$ of ALA per $\mathrm{kg}$ diet & Reduced tumor cell proliferation & Inhibited HER2, EGFR expression & {$[78]$} \\
\hline & $\sim 22.8 \mathrm{~g}$ of ALA per $\mathrm{kg}$ diet & Inhibited MCF-7 cell proliferation & & {$[78]$} \\
\hline & $\sim 11 \mathrm{~g}$ ALA per kg diet & Reduced tumor incidence and burden & Increased $\mathrm{BAX} / \mathrm{Bcl}-2$ ratio & {$[93]$} \\
\hline & $10.6 \mathrm{~g}$ ALA per $\mathrm{kg}$ diet & Decreased tumor growth rate & Inhibited HER2 expression & {$[105]$} \\
\hline & $72 \mu \mathrm{M}$ ALA & Moderate inhibited ER-negative cell proliferation, not affect MCF-7 & NA & {$[124]$} \\
\hline & $30 \mu \mathrm{M}$ of ALA & Slightly inhibited MCF-7 & NA & [122] \\
\hline & NA & Inversely associated with $\mathrm{BC}$ risk & NA & [133] \\
\hline & NA & Inversely correlated with metastasis development & NA & [134] \\
\hline & $55.9 \mathrm{~g}$ ALA per kg diet & Reduced tumor growth and metastasis & NA & [135] \\
\hline & 8 g ALA per kg diet & Decreased tumor growth rate & NA & {$[136]$} \\
\hline & $10 \mathrm{~g}$ ALA per $\mathrm{kg}$ diet & Reduced tumor burden and increased survival rate & NA & [137] \\
\hline & $2.5-40 \mu \mathrm{M}$ of ALA & enhanced cytotoxic effects of Trastuzumab (at $10 \mu \mathrm{M}$ of ALA) & Down-regulated HER2 (at $20 \mu \mathrm{M}$ of ALA) & {$[138]$} \\
\hline & $10 \mu \mathrm{M}$ of ALA & Diminished proteolytic cleavage of the extracellular domain of HER2 & Inhibited HER-2 activity & {$[139]$} \\
\hline & $\sim 21.2 \mathrm{~g}$ of ALA per $\mathrm{kg}$ diet & Minimal inhibited tumor growth w/wo Trastuzumab & NA & {$[140]$} \\
\hline & $52.8 \mathrm{~g}$ of ALA per $\mathrm{kg}$ diet & Inhibited mammary tumor development & NA & [141] \\
\hline
\end{tabular}


Table 7. Cont.

\begin{tabular}{|c|c|c|c|c|}
\hline \multirow{10}{*}{ EPA } & $40-80 \mathrm{~g}$ of EPA per $\mathrm{kg}$ diet & Slowed down tumor growth, reduced tumor burden & Decreased AA derived-eicosanoid & {$[20]$} \\
\hline & $3-100 \mu \mathrm{M}$ of EPA & Induced BC cell apoptosis (at $50 \mu \mathrm{M}$ of EPA) & NA & [86] \\
\hline & $40-200 \mu \mathrm{M}$ of EPA & Restored the growth inhibitory effect of Tamoxifen (at $40 \mu \mathrm{M}$ of EPA) & Decreased pAkt (at $20 \mu \mathrm{M}$ of EPA) & {$[97]$} \\
\hline & $20-80 \mathrm{~g}$ of EPA per kg diet & Inhibited the development of lung metastasis & NA & [126] \\
\hline & $100 \mu \mathrm{M}$ of EPA & Inhibited MCF-7 cell growth & NA & [125] \\
\hline & $40 \mu \mathrm{M}$ of EPA & Induced apoptosis, inhibited cell proliferation, arrested cell cycle at G0/G1 & down-regulated Bcl-2 expression & [142] \\
\hline & $95 \mathrm{~g}$ of EPA per $\mathrm{kg}$ diet & Reduced KPL-1 cell proliferation rate and metastasis & NA & [143] \\
\hline & $42 \mathrm{~g}$ of EPA per $\mathrm{kg}$ diet & Suppressed cell proliferation in MCF-7 xenografts in rats & NA & {$[144]$} \\
\hline & $50 \mu \mathrm{M}$ of EPA & Increased PPAR $\gamma$ at mRNA level & NA & [145] \\
\hline & $0-200 \mu \mathrm{M}$ of EPA & Inhibited MCF-7 cell growth (at $60 \mu \mathrm{M}$ of EPA) & NA & {$[146]$} \\
\hline \multirow{11}{*}{ DHA } & $120 \mu \mathrm{M}$ of DHA & Decreased cancer cell viability, enhanced the cytotoxic activity of taxanes & Decreased the expression of Her-2/neu & [5] \\
\hline & $100 \mu \mathrm{M}$ of $\mathrm{DHA}$ & Disrupted lipid rafts, induced apoptosis in HER-2 overexpressing cells & Decreased Akt activity and FAN & {$[6]$} \\
\hline & $100 \mu \mathrm{M}$ of DHA & Decreased MDA-MB-231 cell proliferation, enhanced EGFR inhibitors & Altered EGFR phosphorylation and localization & {$[56]$} \\
\hline & $0-200 \mu \mathrm{M}$ of DHA & Reduced MCF-7 cell viability and DNA synthesis (at $25 \mu \mathrm{M}$ of DHA) & Increased lipid peroxidation, capase 8 activation & {$[146]$} \\
\hline & 20 or $100 \mu \mathrm{M}$ of DHA & Inhibited MDA-MB-231 cell proliferation, promoted nuclear condensation & Increased caspase- 3 activity (at $100 \mu \mathrm{M}$ of DHA) & [147] \\
\hline & $10-160 \mu \mathrm{M}$ of DHA & Inhibited MCF-7 cell growth and induced apoptosis (at $40 \mu \mathrm{M}$ of DHA) & Downregulated $\mathrm{Bcl}-2$, increased $\mathrm{Bax} / \mathrm{Bcl}-2$ ratio & [148] \\
\hline & $270 \mu \mathrm{M}$ of DHA & $50 \%$ inhibitory KPL-1 cell growth after $72 \mathrm{~h}$ treatment & Downregulated $\mathrm{Bcl}-2$, increased $\mathrm{Bax} / \mathrm{Bcl}-2$ ratio & {$[149]$} \\
\hline & $40 \mathrm{~g}$ of DHA per $\mathrm{kg}$ diet & Decreased tumor growth rate and final tumor weight, increased apoptosis & Reduced tumor PGE2, decreased Ki-67 & {$[150]$} \\
\hline & $32 \mathrm{~g}$ of DHA per $\mathrm{kg}$ diet & Reduced tumor incidence & Increased BRCA1 at protein level & {$[151]$} \\
\hline & $30 \mu \mathrm{M}$ of DHA & $50 \%$ inhibitory MCF7 cell growth after $96 \mathrm{~h}$ treatment & Increased BRCA1/2 at transcriptional level & {$[152]$} \\
\hline & NA & Increased response of the tumor to chemotherapies, increased survival rate & & [153] \\
\hline
\end{tabular}


Table 8. Individual effect of ALA, EPA and DHA on different types of BC.

\begin{tabular}{cccc}
\hline BC Cell Type & ALA & EPA & DHA \\
\hline MDA-MB-231 (ER-) & $\checkmark$ & $\checkmark$ & $\checkmark$ \\
MDA-MB 435 (ER-) & NA & $\checkmark$ & $\checkmark$ \\
MCF-10A (ER-) & - & $\checkmark$ & $\checkmark$ \\
HBL-100 (ER-) & $\checkmark$ & $\checkmark$ & $\checkmark$ \\
MCF-7 (ER+) & - & $\checkmark$ & $\checkmark$ \\
ZR-75 (ER+) & - & $\checkmark$ & $\checkmark$ \\
T-47-D (ER+) & - & $\checkmark$ & $\checkmark$ \\
SK-Br3 and BT-474 & $\checkmark$ & NA & $\checkmark$ \\
(HER-2/neu positive) & & & \\
\hline
\end{tabular}

$\checkmark$ have significant inhibitory effect on cell proliferation; - slightly inhibit the cell growth; NA: not available.

Remarkably, long-term changes in dietary ALA and LA ratio significantly affect mammary tumor outcomes. Feeding BALB/c mice with ALA-rich linseed oil inhibited the development of mammary tumors compared to mice on corn oil diets [135]. In a recent study, use of canola oil (10\% ALA) instead of corn oil (1\% ALA) in the diet of MDA-MB-231 implanted mice reduced tumor growth rate [136]. Progression to apoptosis is associated with a balance between pro-apoptotic Bax and anti-apoptotic $\mathrm{Bcl}-2$. Mice exposed to canola oil had an increased ratio of $\mathrm{Bax} / \mathrm{Bcl}-2$, which was responsible for the apoptosis of defective epithelial cells [93]. Furthermore, the maternal diets have a life-long influence on development of BC in the daughter. Substitution of corn oil with canola oil in the maternal diet increased $n$-3 PUFA incorporation into mammary glands, which in turn delayed occurrence of mammary tumors and increased tumor cell apoptosis in offspring [93]. Elsewhere, maternal replacement of dietary soybean oil with canola oil significantly lowered the burden of MNU-induced mammary tumors, along with increased survival rate in the offspring [137]. As a result, maternal ALA supplementation brings about a stable epigenetic imprint of genes that are involved in the development and differentiation of the mammary gland, which are passed on to female offspring where they exert a protective effect against BC.

Notably, the protective role of ALA in BC was inconclusive in in vitro studies. In BT-474 and SkBr-3 cancer cells that naturally amplify the HER-2 oncogene, exogenous supplementation with ALA significantly suppressed HER-2 mRNA expression, thereby reducing the probability of activation that leads to tumor growth [138]. Moreover, ALA co-exposure was reported to synergistically enhance trastuzumab (an anti-cancer therapy) efficacy in HER2-overexpression BC cells [139]. However, in a separate study, ALA exerted minimal tumor-reducing effects in the presence of trastuzumab [140]. In addition, some studies had difficulties in characterizing the role of ALA in estrogen dependent and independent BC cell lines [122,124]. This suggests a variable effect of ALA on cell proliferation depending on the cell line assessed.

Overall, these findings suggest that diets rich in ALA can inhibit mammary tumor development in animals and in vitro, however, it cannot be ruled out that some of the effects are due in part to conversion of ALA to EPA and DHA, albeit limited. 


\subsection{Individual Effect of EPA on Breast Cancer}

Fish oil is a mixture of EPA and DHA, which have been previously shown to have protective effects against BC. However, whether EPA and DHA differentially or similarly affect BC has not yet been determined. In support of the independent effect of EPA on $\mathrm{BC}$, several in vitro studies consistently demonstrated the ability of EPA to induce apoptosis in human BC cells (Tables 7 and 8). Chiu et al. demonstrated that $40 \mu \mathrm{M}$ EPA induced cell apoptosis through inhibition of anti-apoptotic regulator proteins, such as Bcl-2 [142]. Moreover, Akt was also shown to be susceptible to EPA [97]. Treatment with EPA lowered both total and phosphorylated Akt content in transfected MCF-7 cells that overexpressing constitutively active Akt [97]. Additionally, co-treatment with EPA enhanced the growth inhibitory response to tamoxifen in MCF-7 cells, thus suggesting that EPA may be useful as a nutritional adjuvant in the treatment of $\mathrm{BC}$ [97].

Diets rich in EPA have also been shown to inhibit the growth of spontaneous or transplanted mammary carcinomas in animal models and human clinical trials. EPA was observed to slow tumor growth and reduced metastasis in mice implanted with KPL-1 human BC cells [143]. In a separate study, when compared with LA diet, intake of EPA significantly inhibited tumor cell proliferation and development of lung metastasis in mice with induced mammary tumorigenesis [20,126]. These inhibitory effects were attributed to high incorporation of EPA into tumor phospholipids, and subsequently, disrupting inflammatory eicosanoid biosynthesis from AA [20]. More recently, EPA was found to regulate cell proliferation in MCF-7 xenografts via an inhibitory G protein-coupled receptor-mediated signal transduction pathway [144]. Furthermore, a human clinical study demonstrated a strong positive correlation between plasma EPA concentrations and PPAR $\gamma$ mRNA levels in adipose tissue of obese subjects [145]. Since activators of PPAR $\gamma$ are known to inhibit cell proliferation and tumorigensis, up-regulation of PPAR $\gamma$ gene expression by EPA might be a potential mechanism of action. These findings suggest that EPA can independently act to inhibit the development and progression of human $\mathrm{BC}$.

\subsection{Individual Effect of DHA on Breast Cancer}

Several independent reports have shown that DHA can inhibit mammary carcinoma development and progression (Tables 7 and 8). However, the specific mechanisms underlying these protective effects of DHA remain to be determined.

HER-2 signaling is central to many processes involved in cellular proliferation and survival [6]. Treatment with DHA alone in vitro was shown to be effective in disrupting lipid rafts in HER-2 overexpressing cells, inhibiting HER-2 activity and its downstream signaling molecules (Akt and FAS, etc.), and consequently led to cell death [6]. Menendez et al. demonstrated that exogenous supplementation with DHA was able to downregulate HER-2/neu oncogene expression in SK-Br3 and BT-474 human BC cells [5]. This supports the therapeutic potential of DHA supplementation in the treatment of HER-2 positive BC. On the other hand, recent evidence suggests that DHA itself is capable of decreasing EGFR localization in the lipid rafts of the MDA-MB-231 BC cell line [56]. Moreover, DHA supplementation was reported to significantly enhance the efficacy of EGFR inhibitors, which provides strong evidence for the potential development of combination therapies targeting EGFR [56]. 
The pre-exposure with DHA has been shown to synergistically enhance the cytotoxicity of antimitotic drugs including Taxane and Taxol against highly metastatic BC cells [5]. This was attributed to the incorporation of DHA into cellular lipids, and subsequently altered membrane fluidity and function, thereby increasing drug intake [5]. In agreement with this, a recent human clinical trial demonstrated that addition of DHA into chemotherapy increased survival in metastatic BC patients [154].

A number of earlier studies have suggested that the anti-cancer property of DHA is attributable to its ability to inhibit cell growth and induce apoptosis. Kang et al. demonstrated that DHA induced apoptosis in MCF-7 cells through a combination of pathways [146]. Mechanistically, it was largely due to increased lipid peroxidation, followed by accumulation of reactive oxygen species in cancer cells and higher oxidative stress, ultimately resulting in cell apoptosis [146]. It was also possible that the elevated intracellular levels of DHA stimulated activation of apoptosis effector enzyme, such as caspase- 8 and caspase-3, and thus inducing apoptotic cell death [146,147]. Furthermore, Chiu et al. found that pure DHA inhibited growth of MCF-7 cells [148]. Although DHA did not affect pro-apoptotic Bax protein, it induced the downregulation of anti-apoptotic Bcl-2 gene expression time-dependently, and thus increasing the Bax/Bcl-2 ratio [148]. DHA has also shown to suppress KPL-1 cell growth in vitro, accompanied by downregulation of Bcl-2 [149]. Since the ratio of Bax/Bcl-2 is positively associated with apoptotic activity, the regulation of Bax and Bcl-2 can be considered an important step in the apoptotic actions of DHA.

Animal studies also support the anti-cancer role of DHA in BC. Dietary supplementation of pure DHA was showed to suppress tumor development in both chemically-induced carcinoma and xenograft rodent models [150,151]. Low level DHA administration markedly reduced tumor growth rates and tumor weight compared with rats fed LA [150]. These observed suppressive effects of DHA resulted from diminished tumor eicosanoid concentrations and decreased cell proliferation [150]. DHA has also been shown to decrease mammary tumor incidence coinciding with a $60 \%$ increase in BRCA1 protein, a major tumor suppressor [151]. In complement, DHA supplementation was shown to increase BRCA1 at the transcriptional level [152]. The correlation between the in vitro and in vivo observations adds weight to DHA's potential mechanism and supports a beneficial role for DHA against BC.

Altogether, ALA, EPA and DHA have various effects against mammary tumor development in vivo. In terms of in vitro studies, EPA and DHA individually exert an inhibitory effect on the proliferation of almost all types of tumor cells in vitro; whereas ALA only has effects on ER- and HER-2 positive BC cells (Table 8). As little as $50 \mu \mathrm{M}$ of EPA or $30 \mu \mathrm{M}$ of DHA can dramatically reduce tumor cell viability, while $72 \mu \mathrm{M}$ of ALA only cause moderate inhibition on ER- cell proliferation. However, it is not appropriate to compare the effective dosage of individual $n-3$ PUFA from different type of studies, since the amount of tumor cells and the duration of treatment are different. Additional experimental studies are needed to compare the efficacy of each individual $n-3$ PUFA under the same conditions.

\section{Plant-Derived n-3 (ALA) vs. Marine-Based n-3 (EPA, DHA)}

The potential health benefits of $n-3$ PUFA have been examined in various types of studies. However, the relative potency of plant-based $n$ - 3 versus marine $n-3$ PUFA, as well as EPA versus DHA in inhibiting tumor growth remains unclear. There are only two studies that have compared the efficacy between EPA and DHA [120,155]. The first study compared the ability of dietary EPA or DHA to 
suppress MNU-induced mammary carcinogenesis in a rat model [120]. Although treatment with DHA or EPA alone was not as effective in combination, DHA was more potent in delaying tumor onset and reducing tumor multiplicity relative to EPA [120]. In accordance, several BC cell line studies indicated that DHA was more effective in inhibiting MDA-MB-231 and MCF-7 cell proliferation and invasion than EPA at the same concentration [86,96,121,125,155].

In terms of the efficacy of plant-based $n-3$ PUFA, there has not yet been a human clinical study directly comparing ALA versus EPA or DHA in BC. To the best of our knowledge, only two cell culture studies have examined the effect of different types of $n$-3 PUFA. ALA was less effective compared with EPA or DHA, but ALA had moderate inhibitory effects in some BC cell lines $[122,124]$. This may be due to the conversion of ALA to EPA and DHA which would lower the amount of ALA incubated with cancer cells. In addition, the lower incorporation of ALA into the cellular lipid pool may also be a confounding factor.

\section{Conclusions}

In summary, the present review has assessed the anticancer effects of $n$-3 PUFA when consumed or treated individually, as well as in $n-3$ PUFA mixtures. ALA, EPA and DHA can differentially inhibit mammary tumor development by changing the cell membrane fatty acid composition, suppressing AA-derived eicosanoid biosynthesis and influencing signaling transcriptional pathways to inhibit cell proliferation and induce apoptosis. This review also provided evidence for using $n-3$ PUFA as a nutritional intervention in the treatment of $\mathrm{BC}$ to enhance conventional therapeutics, or potentially lowering effective doses.

Overall, in order to provide definitive recommendations, additional human studies are required. Long term studies tracking fish or $n$-3 PUFA intake are needed to demonstrate a role for $n-3$ PUFA in prevention. Also, additional clinical trials are needed to evaluate the effect $n$-3 PUFA on BC outcomes. Nevertheless, evidence does not indicate harm and all forms of $n-3$ PUFA may be included in a healthy diet.

\section{Acknowledgments}

Funding from a Canadian Institutes of Health Research operating grant (89971) is provided to D.W.L. Ma. Jiajie Liu is supported by Ontario Graduate Scholarship.

\section{Conflict of Interest}

The authors declare no conflict of interest.

\section{References}

1. DeSantis, C.; Ma, J.; Bryan, L.; Jemal, A. Breast cancer statistics, 2013. CA Cancer J. Clin. 2014, 64, 52-62.

2. Canadian Cancer Statistics. Canadian Cancer Society's Advisory; Canadian Cancer statistics: Toronto, ON, Canada, 2013. 
3. Gerber, M. Omega-3 fatty acids and cancers: A systematic update review of epidemiological studies. Br. J. Nutr. 2012, 107 (Suppl. 2), S228-S239.

4. Iwasaki, M.; Tsugane, S. Risk factors for breast cancer: Epidemiological evidence from Japanese studies. Cancer Sci. 2011, 102, 1607-1614.

5. Menendez, J.A.; Lupu, R.; Colomer, R. Exogenous supplementation with omega-3 polyunsaturated fatty acid docosahexaenoic acid (DHA; 22:6n-3) synergistically enhances taxane cytotoxicity and downregulates Her-2/neu (c-erbB-2) oncogene expression in human breast cancer cells. Eur. J. Cancer Prev. 2005, 14, 263-270.

6. Ravacci, G.R.; Brentani, M.M.; Tortelli, T., Jr.; Torrinhas, R.S.; Saldanha, T.; Torres, E.A.; Waitzberg, D.L. Lipid raft disruption by docosahexaenoic acid induces apoptosis in transformed human mammary luminal epithelial cells harboring HER-2 overexpression. J. Nutr. Biochem. 2013, 24, 505-515.

7. Zheng, J.S.; Hu, X.J.; Zhao, Y.M.; Yang, J.; Li, D. Intake of fish and marine $n$-3 polyunsaturated fatty acids and risk of breast cancer: Meta-analysis of data from 21 independent prospective cohort studies. BMJ 2013, 346, doi:10.1136/bmj.f3706.

8. Simopoulos, A.P. The importance of the ratio of omega-6/omega-3 essential fatty acids. Biomed. Pharmacother. 2002, 56, 365-379.

9. Saadatian-Elahi, M.; Norat, T.; Goudable, J.; Riboli, E. Biomarkers of dietary fatty acid intake and the risk of breast cancer: A meta-analysis. Int. J. Cancer 2004, 111, 584-591.

10. Boyd, N.F.; Stone, J.; Vogt, K.N.; Connelly, B.S.; Martin, L.J.; Minkin, S. Dietary fat and breast cancer risk revisited: A meta-analysis of the published literature. Br. J. Cancer 2003, 89, 1672-1685.

11. Anderson, B.M.; Ma, D.W. Are all n-3 polyunsaturated fatty acids created equal? Lipids Health Dis. 2009, 8, 33.

12. Zou, Z.; Bidu, C.; Bellenger, S.; Narce, M.; Bellenger, J. n-3 polyunsaturated fatty acids and HER2-positive breast cancer: Interest of the fat-1 transgenic mouse model over conventional dietary supplementation. Biochimie 2014, 96, 22-27.

13. Murray, M. $\omega-3$ Polyunsaturated fatty acids and their metabolites as inhibitors of mammalian tumorigenesis. Phytochem. Rev. 2014, 13, 139-156.

14. Akhtar, S.; Ismail, T.; Riaz, M. Flaxseed-A miraculous defense against some critical maladies. Pak. J. Pharm. Sci. 2013, 26, 199-208.

15. Kris-Etherton, P.M.; Harris, W.S.; Appel, L.J. Fish consumption, fish oil, omega-3 fatty acids, and cardiovascular disease. Circulation 2002, 106, 2747-2757.

16. Institute of Medicine of the National Academies. Dietary Reference Intakes for Energy, Carbohydrate, Fiber, Fat, Fatty Acids, Cholesterol, Protein, and Amino Acids; The National Academies Press: Washington, DC, USA, 2005.

17. Vannice, G.; Rasmussen, H. Position of the academy of nutrition and dietetics: Dietary fatty acids for healthy adults. J. Acad. Nutr. Diet. 2014, 114, 136-153.

18. Bagga, D.; Anders, K.H.; Wang, H.J.; Glaspy, J.A. Long-chain $n$-3-to- $n-6$ polyunsaturated fatty acid ratios in breast adipose tissue from women with and without breast cancer. Nutr. Cancer $\mathbf{2 0 0 2}$, 42, 180-185. 
19. Chajes, V.; Torres-Mejia, G.; Biessy, C.; Ortega-Olvera, C.; ngeles-Llerenas, A.; Ferrari, P.; Lazcano-Ponce, E.; Romieu, I. omega-3 and omega-6 Polyunsaturated fatty acid intakes and the risk of breast cancer in Mexican women: Impact of obesity status. Cancer Epidemiol. Biomark. Prev. 2012, 21, 319-326.

20. Rose, D.P.; Connolly, J.M.; Rayburn, J.; Coleman, M. Influence of diets containing eicosapentaenoic or docosahexaenoic acid on growth and metastasis of breast cancer cells in nude mice. J. Natl. Cancer Inst. 1995, 87, 587-592.

21. Leslie, M.A.; Abdelmagid, S.A.; Perez, K.; Muller, W.J.; Ma, D.W. Mammary tumour development is dose-dependently inhibited by $n-3$ polyunsaturated fatty acids in the MMTV-neu(ndl)-YD5 transgenic mouse model. Lipids Health Dis. 2014, 13, 96.

22. Schley, P.D.; Brindley, D.N.; Field, C.J. (n-3) PUFA alter raft lipid composition and decrease epidermal growth factor receptor levels in lipid rafts of human breast cancer cells. J. Nutr. 2007, $137,548-553$.

23. Silva, V.; Barazzoni, R.; Singer, P. Biomarkers of fish oil omega-3 polyunsaturated fatty acids intake in humans. Nutr. Clin. Pract. 2014, 29, 63-72.

24. Ziegler, R.G.; Hoover, R.N.; Pike, M.C.; Hildesheim, A.; Nomura, A.M.; West, D.W.; Wu-Williams, A.H.; Kolonel, L.N.; Horn-Ross, P.L.; Rosenthal, J.F.; et al. Migration patterns and breast cancer risk in Asian-American women. J. Natl. Cancer Inst. 1993, 85, 1819-1827.

25. Singh, G.K.; Hiatt, R.A. Trends and disparities in socioeconomic and behavioural characteristics, life expectancy, and cause-specific mortality of native-born and foreign-born populations in the United States, 1979-2003. Int. J. Epidemiol. 2006, 35, 903-919.

26. Manna, S.; Janarthan, M.; Ghosh, B.; Rana, B.; Rana, A.; Chatterjee, M. Fish oil regulates cell proliferation, protect DNA damages and decrease HER-2/neu and c-Myc protein expression in rat mammary carcinogenesis. Clin. Nutr. 2010, 29, 531-537.

27. Manna, S.; Chakraborty, T.; Ghosh, B.; Chatterjee, M.; Panda, A.; Srivastava, S.; Rana, A.; Chatterjee, M. Dietary fish oil associated with increased apoptosis and modulated expression of Bax and Bcl-2 during 7,12-dimethylbenz $(\alpha)$ anthracene-induced mammary carcinogenesis in rats. Prostaglandins Leukot. Essent. Fatty Acids 2008, 79, 5-14.

28. Manna, S.; Chakraborty, T.; Damodaran, S.; Samanta, K.; Rana, B.; Chatterjee, M. Protective role of fish oil (Maxepa) on early events of rat mammary carcinogenesis by modulation of DNA-protein crosslinks, cell proliferation and p53 expression. Cancer Cell Int. 2007, 7, 6.

29. Su, H.M.; Hsieh, P.H.; Chen, H.F. A maternal high $n-6$ fat diet with fish oil supplementation during pregnancy and lactation in rats decreases breast cancer risk in the female offspring. J. Nutr. Biochem. 2010, 21, 1033-1037.

30. Hardman, W.E.; Avula, C.P.; Fernandes, G.; Cameron, I.L. Three percent dietary fish oil concentrate increased efficacy of doxorubicin against MDA-MB 231 breast cancer xenografts. Clin. Cancer Res. 2001, 7, 2041-2049.

31. Larsson, S.C.; Kumlin, M.; Ingelman-Sundberg, M.; Wolk, A. Dietary long-chain $n$-3 fatty acids for the prevention of cancer: A review of potential mechanisms. Am. J. Clin. Nutr. 2004, 79, 935-945. 
32. Terry, P.D.; Rohan, T.E.; Wolk, A. Intakes of fish and marine fatty acids and the risks of cancers of the breast and prostate and of other hormone-related cancers: A review of the epidemiologic evidence. Am. J. Clin. Nutr. 2003, 77, 532-543.

33. Stoll, B.A. $n$-3 fatty acids and lipid peroxidation in breast cancer inhibition. Br. J. Nutr. 2002, 87, 193-198.

34. MacLennan, M.; Ma, D.W. Role of dietary fatty acids in mammary gland development and breast cancer. Breast Cancer Res. 2010, 12, 211.

35. Wakai, K.; Tamakoshi, K.; Date, C.; Fukui, M.; Suzuki, S.; Lin, Y.; Niwa, Y.; Nishio, K.; Yatsuya, H.; Kondo, T.; et al. Dietary intakes of fat and fatty acids and risk of breast cancer: A prospective study in Japan. Cancer Sci. 2005, 96, 590-599.

36. Gago-Dominguez, M.; Yuan, J.M.; Sun, C.L.; Lee, H.P.; Yu, M.C. Opposing effects of dietary n-3 and n-6 fatty acids on mammary carcinogenesis: The Singapore Chinese Health Study. Br. J. Cancer 2003, 89, 1686-1692.

37. Murff, H.J.; Shu, X.O.; Li, H.; Yang, G.; Wu, X.; Cai, H.; Wen, W.; Gao, Y.T.; Zheng, W. Dietary polyunsaturated fatty acids and breast cancer risk in Chinese women: A prospective cohort study. Int. J. Cancer 2011, 128, 1434-1441.

38. Shannon, J.; King, I.B.; Lampe, J.W.; Gao, D.L.; Ray, R.M.; Lin, M.G.; Stalsberg, H.; Thomas, D.B. Erythrocyte fatty acids and risk of proliferative and nonproliferative fibrocystic disease in women in Shanghai, China. Am. J. Clin. Nutr. 2009, 89, 265-276.

39. Kim, J.; Lim, S.Y.; Shin, A.; Sung, M.K.; Ro, J.; Kang, H.S.; Lee, K.S.; Kim, S.W.; Lee, E.S. Fatty fish and fish omega-3 fatty acid intakes decrease the breast cancer risk: A case-control study. BMC Cancer 2009, 9, 216.

40. Brasky, T.M.; Lampe, J.W.; Potter, J.D.; Patterson, R.E.; White, E. Specialty supplements and breast cancer risk in the VITamins And Lifestyle (VITAL) Cohort. Cancer Epidemiol. Biomark. Prev. 2010, 19, 1696-1708.

41. Goodstine, S.L.; Zheng, T.; Holford, T.R.; Ward, B.A.; Carter, D.; Owens, P.H.; Mayne, S.T. Dietary $(n-3) /(n-6)$ fatty acid ratio: Possible relationship to premenopausal but not postmenopausal breast cancer risk in U.S. women. J. Nutr. 2003, 133, 1409-1414.

42. Thiebaut, A.C.; Chajes, V.; Gerber, M.; Boutron-Ruault, M.C.; Joulin, V.; Lenoir, G.; Berrino, F.; Riboli, E.; Benichou, J.; Clavel-Chapelon, F. Dietary intakes of omega-6 and omega-3 polyunsaturated fatty acids and the risk of breast cancer. Int. J. Cancer 2009, 124, 924-931.

43. Stripp, C.; Overvad, K.; Christensen, J.; Thomsen, B.L.; Olsen, A.; Moller, S.; Tjonneland, A. Fish intake is positively associated with breast cancer incidence rate. J. Nutr. 2003, 133, 3664-3669.

44. Witt, P.M.; Christensen, J.H.; Schmidt, E.B.; Dethlefsen, C.; Tjonneland, A.; Overvad, K.; Ewertz, M. Marine $n-3$ polyunsaturated fatty acids in adipose tissue and breast cancer risk: A case-cohort study from Denmark. Cancer Causes Control 2009, 20, 1715-1721.

45. Maillard, V.; Bougnoux, P.; Ferrari, P.; Jourdan, M.L.; Pinault, M.; Lavillonniere, F.; Body, G.; Le, F.O.; Chajes, V. n-3 and n-6 fatty acids in breast adipose tissue and relative risk of breast cancer in a case-control study in Tours, France. Int. J. Cancer 2002, 98, 78-83. 
46. Kuriki, K.; Hirose, K.; Wakai, K.; Matsuo, K.; Ito, H.; Suzuki, T.; Hiraki, A.; Saito, T.; Iwata, H.; Tatematsu, M.; et al. Breast cancer risk and erythrocyte compositions of $n$-3 highly unsaturated fatty acids in Japanese. Int. J. Cancer 2007, 121, 377-385.

47. Shannon, J.; King, I.B.; Moshofsky, R.; Lampe, J.W.; Gao, D.L.; Ray, R.M.; Thomas, D.B. Erythrocyte fatty acids and breast cancer risk: A case-control study in Shanghai, China. Am. J. Clin. Nutr. 2007, 85, 1090-1097.

48. Patterson, R.E.; Flatt, S.W.; Newman, V.A.; Natarajan, L.; Rock, C.L.; Thomson, C.A.; Caan, B.J.; Parker, B.A.; Pierce, J.P. Marine fatty acid intake is associated with breast cancer prognosis. J. Nutr. 2011, 141, 201-206.

49. Signori, C.; DuBrock, C.; Richie, J.P.; Prokopczyk, B.; Demers, L.M.; Hamilton, C.; Hartman, T.J.; Liao, J.; El-Bayoumy, K.; Manni, A. Administration of omega-3 fatty acids and Raloxifene to women at high risk of breast cancer: Interim feasibility and biomarkers analysis from a clinical trial. Eur. J. Clin. Nutr. 2012, 66, 878-884.

50. Thompson, L.U.; Chen, J.M.; Li, T.; Strasser-Weippl, K.; Goss, P.E. Dietary flaxseed alters tumor biological markers in postmenopausal breast cancer. Clin. Cancer Res. 2005, 11, 3828-3835.

51. Menendez, J.A.; Lupu, R. Fatty acid synthase and the lipogenic phenotype in cancer pathogenesis. Nat. Rev. Cancer 2007, 7, 763-777.

52. Gu, Z.; Suburu, J.; Chen, H.; Chen, Y.Q. Mechanisms of omega-3 polyunsaturated fatty acids in prostate cancer prevention. Biomed. Res. Int. 2013, 2013, doi:10.1155/2013/824563.

53. Wassall, S.R.; Stillwell, W. Docosahexaenoic acid domains: The ultimate non-raft membrane domain. Chem. Phys. Lipids 2008, 153, 57-63.

54. Chenais, B.; Blanckaert, V. The Janus face of lipids in human breast cancer: How polyunsaturated Fatty acids affect tumor cell hallmarks. Int. J. Breast Cancer 2012, 2012, doi:10.1155/2012/712536.

55. Murai, T. The role of lipid rafts in cancer cell adhesion and migration. Int. J. Cell Biol. 2012, 2012, doi:10.1155/2012/763283.

56. Rogers, K.R.; Kikawa, K.D.; Mouradian, M.; Hernandez, K.; McKinnon, K.M.; Ahwah, S.M.; Pardini, R.S. Docosahexaenoic acid alters epidermal growth factor receptor-related signaling by disrupting its lipid raft association. Carcinogenesis 2010, 31, 1523-1530.

57. Ma, D.W.; Seo, J.; Davidson, L.A.; Callaway, E.S.; Fan, Y.Y.; Lupton, J.R.; Chapkin, R.S. n-3 PUFA alter caveolae lipid composition and resident protein localization in mouse colon. FASEB J. 2004, 18, 1040-1042.

58. Burdge, G.C.; Calder, P.C. Conversion of $\alpha$-linolenic acid to longer-chain polyunsaturated fatty acids in human adults. Reprod. Nutr. Dev. 2005, 45, 581-597.

59. Young, L.R.; Kurzer, M.S.; Thomas, W.; Redmon, J.B.; Raatz, S.K. Effect of dietary fat and omega-3 fatty acids on urinary eicosanoids and sex hormone concentrations in postmenopausal women: A randomized controlled feeding trial. Nutr. Cancer 2011, 63, 930-939.

60. Healy, D.A.; Wallace, F.A.; Miles, E.A.; Calder, P.C.; Newsholm, P. Effect of low-to-moderate amounts of dietary fish oil on neutrophil lipid composition and function. Lipids 2000, 35, $763-768$.

61. Benoit, V.; Relic, B.; Leval, X.X.; Chariot, A.; Merville, M.P.; Bours, V. Regulation of HER-2 oncogene expression by cyclooxygenase-2 and prostaglandin E2. Oncogene 2004, 23, 1631-1635. 
62. Richards, J.A.; Brueggemeier, R.W. Prostaglandin E2 regulates aromatase activity and expression in human adipose stromal cells via two distinct receptor subtypes. J. Clin. Endocrinol. Metab. 2003, 88, 2810-2816.

63. Kelley, D.S.; Taylor, P.C.; Nelson, G.J.; Schmidt, P.C.; Ferretti, A.; Erickson, K.L.; Yu, R.; Chandra, R.K.; Mackey, B.E. Docosahexaenoic acid ingestion inhibits natural killer cell activity and production of inflammatory mediators in young healthy men. Lipids 1999, 34, 317-324.

64. Wei, N.; Wang, B.; Zhang, Q.Y.; Mi, M.T.; Zhu, J.D.; Yu, X.P.; Yuan, J.L.; Chen, K.; Wang, J.; Chang, H. Effects of different dietary fatty acids on the fatty acid compositions and the expression of lipid metabolic-related genes in mammary tumor tissues of rats. Nutr. Cancer 2008, 60, $810-825$.

65. Serhan, C.N. Novel eicosanoid and docosanoid mediators: Resolvins, docosatrienes, and neuroprotectins. Curr. Opin. Clin. Nutr. Metab. Care 2005, 8, 115-121.

66. Serhan, C.N.; Arita, M.; Hong, S.; Gotlinger, K. Resolvins, docosatrienes, and neuroprotectins, novel omega-3-derived mediators, and their endogenous aspirin-triggered epimers. Lipids 2004, 39, 1125-1132.

67. Weylandt, K.H.; Kang, J.X.; Wiedenmann, B.; Baumgart, D.C. Lipoxins and resolvins in inflammatory bowel disease. Inflamm. Bowel. Dis. 2007, 13, 797-799.

68. Kang, J.X.; Weylandt, K.H. Modulation of inflammatory cytokines by omega-3 fatty acids. Subcell. Biochem. 2008, 49, 133-143.

69. Calder, P.C. $n-3$ polyunsaturated fatty acids, inflammation, and inflammatory diseases. Am. J. Clin. Nutr. 2006, 83, 1505S-1519S.

70. Zandi, R.; Larsen, A.B.; Andersen, P.; Stockhausen, M.T.; Poulsen, H.S. Mechanisms for oncogenic activation of the epidermal growth factor receptor. Cell Signal. 2007, 19, 2013-2023.

71. Corsetto, P.A.; Montorfano, G.; Zava, S.; Jovenitti, I.E.; Cremona, A.; Berra, B.; Rizzo, A.M. Effects of $n$-3 PUFAs on breast cancer cells through their incorporation in plasma membrane. Lipids Health Dis. 2011, 10, 73.

72. Bhargava, R.; Gerald, W.L.; Li, A.R.; Pan, Q.; Lal, P.; Ladanyi, M.; Chen, B. EGFR gene amplification in breast cancer: Correlation with epidermal growth factor receptor mRNA and protein expression and HER-2 status and absence of EGFR-activating mutations. Mod. Pathol. 2005, 18, 1027-1033.

73. Hynes, N.E.; Stern, D.F. The biology of erbB-2/neu/HER-2 and its role in cancer. Biochim. Biophys. Acta 1994, 1198, 165-184.

74. Tovey, S.M.; Brown, S.; Doughty, J.C.; Mallon, E.A.; Cooke, T.G.; Edwards, J. Poor survival outcomes in HER2-positive breast cancer patients with low-grade, node-negative tumours. Br. J. Cancer 2009, 100, 680-683.

75. Moasser, M.M. The oncogene HER2: Its signaling and transforming functions and its role in human cancer pathogenesis. Oncogene 2007, 26, 6469-6487.

76. Bollig-Fischer, A.; Dziubinski, M.; Boyer, A.; Haddad, R.; Giroux, C.N.; Ethier, S.P. HER-2 signaling, acquisition of growth factor independence, and regulation of biological networks associated with cell transformation. Cancer Res. 2010, 70, 7862-7873. 
77. Yee, L.D.; Agarwal, D.; Rosol, T.J.; Lehman, A.; Tian, M.; Hatton, J.; Heestand, J.; Belury, M.A.; Clinton, S.K. The inhibition of early stages of HER-2/neu-mediated mammary carcinogenesis by dietary n-3 PUFAs. Mol. Nutr. Food Res. 2013, 57, 320-327.

78. Truan, J.S.; Chen, J.M.; Thompson, L.U. Flaxseed oil reduces the growth of human breast tumors (MCF-7) at high levels of circulating estrogen. Mol. Nutr. Food Res. 2010, 54, 1414-1421.

79. Desvergne, B.; Wahli, W. Peroxisome proliferator-activated receptors: Nuclear control of metabolism. Endocr. Rev. 1999, 20, 649-688.

80. Georgiadi, A.; Kersten, S. Mechanisms of gene regulation by fatty acids. Adv. Nutr. 2012, 3, 127-134.

81. Gurnell, M.; Savage, D.B.; Chatterjee, V.K.; O’Rahilly, S. The metabolic syndrome: Peroxisome proliferator-activated receptor gamma and its therapeutic modulation. J. Clin. Endocrinol. Metab. 2003, 88, 2412-2421.

82. Flachs, P.; Rossmeisl, M.; Bryhn, M.; Kopecky, J. Cellular and molecular effects of n-3 polyunsaturated fatty acids on adipose tissue biology and metabolism. Clin. Sci. 2009, 116, 1-16.

83. Kliewer, S.A.; Sundseth, S.S.; Jones, S.A.; Brown, P.J.; Wisely, G.B.; Koble, C.S.; Devchand, P.; Wahli, W.; Willson, T.M.; Lenhard, J.M.; et al. Fatty acids and eicosanoids regulate gene expression through direct interactions with peroxisome proliferator-activated receptors alpha and gamma. Proc. Natl. Acad. Sci. USA 1997, 94, 4318-4323.

84. Clay, C.E.; Namen, A.M.; Atsumi, G.; Willingham, M.C.; High, K.P.; Kute, T.E.; Trimboli, A.J.; Fonteh, A.N.; Dawson, P.A.; Chilton, F.H. Influence of J series prostaglandins on apoptosis and tumorigenesis of breast cancer cells. Carcinogenesis 1999, 20, 1905-1911.

85. Mueller, E.; Sarraf, P.; Tontonoz, P.; Evans, R.M.; Martin, K.J.; Zhang, M.; Fletcher, C.; Singer, S.; Spiegelman, B.M. Terminal differentiation of human breast cancer through PPAR gamma. Mol. Cell 1998, 1, 465-470.

86. Barascu, A.; Besson, P.; Le, F.O.; Bougnoux, P.; Jourdan, M.L. CDK1-cyclin B1 mediates the inhibition of proliferation induced by omega-3 fatty acids in MDA-MB-231 breast cancer cells. Int. J. Biochem. Cell Biol. 2006, 38, 196-208.

87. Jiang, W.; Zhu, Z.; McGinley, J.N.; El, B.K.; Manni, A.; Thompson, H.J. Identification of a molecular signature underlying inhibition of mammary carcinoma growth by dietary $n-3$ fatty acids. Cancer Res. 2012, 72, 3795-3806.

88. Elmore, S. Apoptosis: A review of programmed cell death. Toxicol. Pathol. 2007, 35, 495-516.

89. Jacobson, M.D.; Burne, J.F.; King, M.P.; Miyashita, T.; Reed, J.C.; Raff, M.C. Bcl-2 blocks apoptosis in cells lacking mitochondrial DNA. Nature 1993, 361, 365-369.

90. Van Slooten, H.J.; Clahsen, P.C.; van Dierendonck, J.H.; Duval, C.; Pallud, C.; Mandard, A.M.; obelle-Deroide, A.; van de Velde, C.J.; van de Vijver, M.J. Expression of Bcl-2 in node-negative breast cancer is associated with various prognostic factors, but does not predict response to one course of perioperative chemotherapy. Br. J. Cancer 1996, 74, 78-85.

91. Oltvai, Z.N.; Milliman, C.L.; Korsmeyer, S.J. Bcl-2 heterodimerizes in vivo with a conserved homolog, Bax, that accelerates programmed cell death. Cell 1993, 74, 609-619.

92. Raisova, M.; Hossini, A.M.; Eberle, J.; Riebeling, C.; Wieder, T.; Sturm, I.; Daniel, P.T.; Orfanos, C.E.; Geilen, C.C. The Bax/Bcl-2 ratio determines the susceptibility of human melanoma cells to CD95/Fas-mediated apoptosis. J. Investig. Dermatol. 2001, 117, 333-340. 
93. Ion, G.; Akinsete, J.A.; Hardman, W.E. Maternal consumption of canola oil suppressed mammary gland tumorigenesis in C3(1) TAg mice offspring. BMC Cancer 2010, 10, 81.

94. Vivanco, I.; Sawyers, C.L. The phosphatidylinositol 3-Kinase AKT pathway in human cancer. Nat. Rev. Cancer 2002, 2, 489-501.

95. Bai, D.; Ueno, L.; Vogt, P.K. Akt-mediated regulation of NFאB and the essentialness of NFkB for the oncogenicity of PI3K and Akt. Int. J. Cancer 2009, 125, 2863-2870.

96. Schley, P.D.; Jijon, H.B.; Robinson, L.E.; Field, C.J. Mechanisms of omega-3 fatty acid-induced growth inhibition in MDA-MB-231 human breast cancer cells. Breast Cancer Res. Treat. 2005, 92, 187-195.

97. DeGraffenried, L.A.; Friedrichs, W.E.; Fulcher, L.; Fernandes, G.; Silva, J.M.; Peralba, J.M.; Hidalgo, M. Eicosapentaenoic acid restores tamoxifen sensitivity in breast cancer cells with high Akt activity. Ann. Oncol. 2003, 14, 1051-1056.

98. Nicholson, K.M.; Anderson, N.G. The protein kinase B/Akt signalling pathway in human malignancy. Cell Signal. 2002, 14, 381-395.

99. Hussain, A.R.; Ahmed, S.O.; Ahmed, M.; Khan, O.S.; Al, A.S.; Platanias, L.C.; Al-Kuraya, K.S.; Uddin, S. Cross-talk between $\mathrm{NF \kappa B}$ and the PI3-kinase/AKT pathway can be targeted in primary effusion lymphoma (PEL) cell lines for efficient apoptosis. PLoS One 2012, 7, doi:10.1371/journal.pone.0039945.

100. Dolcet, X.; Llobet, D.; Pallares, J.; Matias-Guiu, X. NF-кB in development and progression of human cancer. Virchows Arch. 2005, 446, 475-482.

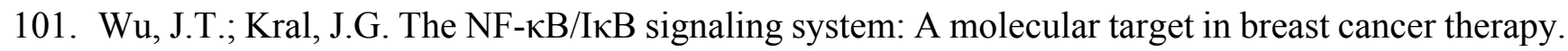
J. Surg. Res. 2005, 123, 158-169.

102. Mayo, M.W.; Wang, C.Y.; Cogswell, P.C.; Rogers-Graham, K.S.; Lowe, S.W.; Der, C.J.; Baldwin, A.S., Jr. Requirement of NF- $\mathrm{BB}$ activation to suppress p53-independent apoptosis induced by oncogenic Ras. Science 1997, 278, 1812-1815.

103. Yerushalmi, R.; Woods, R.; Ravdin, P.M.; Hayes, M.M.; Gelmon, K.A. Ki67 in breast cancer: Prognostic and predictive potential. Lancet Oncol. 2010, 11, 174-183.

104. Scholzen, T.; Gerdes, J. The Ki-67 protein: From the known and the unknown. J. Cell. Physiol. 2000, 182, 311-322.

105. Saggar, J.K.; Chen, J.; Corey, P.; Thompson, L.U. Dietary flaxseed lignan or oil combined with tamoxifen treatment affects MCF-7 tumor growth through estrogen receptor- and growth factor-signaling pathways. Mol. Nutr. Food Res. 2010, 54, 415-425.

106. Taftachi, R.; Ayhan, A.; Ekici, S.; Ergen, A.; Ozen, H. Proliferating-cell nuclear antigen (PCNA) as an independent prognostic marker in patients after prostatectomy: A comparison of PCNA and Ki-67. BJU Int. 2005, 95, 650-654.

107. Paunesku, T.; Mittal, S.; Protić, M.; Oryhon, J.; Korolev, S.V.; Joachimiak, A.; Woloschak, G.E. Proliferating cell nuclear antigen (PCNA): Ringmaster of the genome. Int. J. Radiat. Biol. 2001, 77, 1007-1021.

108. Malkas, L.H.; Herbert, B.S.; bdel-Aziz, W.; Dobrolecki, L.E.; Liu, Y.; Agarwal, B.; Hoelz, D.; Badve, S.; Schnaper, L.; Arnold, R.J.; et al. A cancer-associated PCNA expressed in breast cancer has implications as a potential biomarker. Proc. Natl. Acad. Sci. USA 2006, 103, 19472-19477. 
109. Strzalka, W.; Ziemienowicz, A. Proliferating cell nuclear antigen (PCNA): A key factor in DNA replication and cell cycle regulation. Ann. Bot. 2011, 107, 1127-1140.

110. Olivo, S.E.; Hilakivi-Clarke, L. Opposing effects of prepubertal low- and high-fat $n-3$ polyunsaturated fatty acid diets on rat mammary tumorigenesis. Carcinogenesis 2005, 26, 1563-1572.

111. Kim, I.S.; Baek, S.H. Mouse models for breast cancer metastasis. Biochem. Biophys. Res. Commun. 2010, 394, 443-447.

112. Karmali, R.A.; Marsh, J.; Fuchs, C. Effect of omega-3 fatty acids on growth of a rat mammary tumor. J. Natl. Cancer Inst. 1984, 73, 457-461.

113. Gonzalez, M.J.; Schemmel, R.A.; Gray, J.I.; Dugan, L., Jr.; Sheffield, L.G.; Welsch, C.W. Effect of dietary fat on growth of MCF-7 and MDA-MB231 human breast carcinomas in athymic nude mice: Relationship between carcinoma growth and lipid peroxidation product levels. Carcinogenesis 1991, 12, 1231-1235.

114. Hubbard, N.E.; Lim, D.; Erickson, K.L. Alteration of murine mammary tumorigenesis by dietary enrichment with $n$-3 fatty acids in fish oil. Cancer Lett. 1998, 124, 1-7.

115. Yee, L.D.; Young, D.C.; Rosol, T.J.; Vanbuskirk, A.M.; Clinton, S.K. Dietary (n-3) polyunsaturated fatty acids inhibit HER-2/neu-induced breast cancer in mice independently of the PPARgamma ligand rosiglitazone. J. Nutr. 2005, 135, 983-988.

116. MacLennan, M.B.; Clarke, S.E.; Perez, K.; Wood, G.A.; Muller, W.J.; Kang, J.X.; Ma, D.W. Mammary tumor development is directly inhibited by lifelong $n-3$ polyunsaturated fatty acids. J. Nutr. Biochem. 2013, 24, 388-395.

117. Dankort, D.; Maslikowski, B.; Warner, N.; Kanno, N.; Kim, H.; Wang, Z.; Moran, M.F.; Oshima, R.G.; Cardiff, R.D.; Muller, W.J. Grb2 and Shc adapter proteins play distinct roles in Neu (ErbB-2)-induced mammary tumorigenesis: Implications for human breast cancer. Mol. Cell Biol. 2001, 21, 1540-1551.

118. Yee, L.D.; Lester, J.L.; Cole, R.M.; Richardson, J.R.; Hsu, J.C.; Li, Y.; Lehman, A.; Belury, M.A.; Clinton, S.K. Omega-3 fatty acid supplements in women at high risk of breast cancer have dose-dependent effects on breast adipose tissue fatty acid composition. Am. J. Clin. Nutr. 2010, 91, 1185-1194.

119. Luijten, M.; Verhoef, A.; Dormans, J.A.; Beems, R.B.; Cremers, H.W.; Nagelkerke, N.J.; Adlercreutz, H.; Penalvo, J.L.; Piersma, A.H. Modulation of mammary tumor development in Tg.NK (MMTV/c-neu) mice by dietary fatty acids and life stage-specific exposure to phytoestrogens. Reprod. Toxicol. 2007, 23, 407-413.

120. Yuri, T.; Danbara, N.; Tsujita-Kyutoku, M.; Fukunaga, K.; Takada, H.; Inoue, Y.; Hada, T.; Tsubura, A. Dietary docosahexaenoic acid suppresses $N$-methyl- $N$-nitrosourea-induced mammary carcinogenesis in rats more effectively than eicosapentaenoic acid. Nutr. Cancer 2003, 45, 211-217.

121. Rose, D.P.; Connolly, J.M. Effects of fatty acids and inhibitors of eicosanoid synthesis on the growth of a human breast cancer cell line in culture. Cancer Res. 1990, 50, 7139-7144.

122. Grammatikos, S.I.; Subbaiah, P.V.; Victor, T.A.; Miller, W.M. $n-3$ and $n-6$ fatty acid processing and growth effects in neoplastic and non-cancerous human mammary epithelial cell lines. Br. J. Cancer 1994, 70, 219-227. 
123. Kachhap, S.K.; Dange, P.P.; Santani, R.H.; Sawant, S.S.; Ghosh, S.N. Effect of omega-3 fatty acid (docosahexanoic acid) on BRCA1 gene expression and growth in MCF-7 cell line. Cancer Biother. Radiopharm. 2001, 16, 257-263.

124. Chajes, V.; Sattler, W.; Stranzl, A.; Kostner, G.M. Influence of $n-3$ fatty acids on the growth of human breast cancer cells in vitro: Relationship to peroxides and vitamin-E. Breast Cancer Res. Treat. 1995, 34, 199-212.

125. Chamras, H.; Ardashian, A.; Heber, D.; Glaspy, J.A. Fatty acid modulation of MCF-7 human breast cancer cell proliferation, apoptosis and differentiation. J. Nutr. Biochem. 2002, 13, 711-716.

126. Rose, D.P.; Connolly, J.M.; Coleman, M. Effect of $\omega-3$ fatty acids on the progression of metastases after the surgical excision of human breast cancer cell solid tumors growing in nude mice. Clin. Cancer Res. 1996, 2, 1751-1756.

127. Arterburn, L.M.; Hall, E.B.; Oken, H. Distribution, interconversion, and dose response of $n-3$ fatty acids in humans. Am. J. Clin. Nutr. 2006, 83, 1467S-1476S.

128. Harper, C.R.; Edwards, M.J.; DeFilippis, A.P.; Jacobson, T.A. Flaxseed oil increases the plasma concentrations of cardioprotective (n-3) fatty acids in humans. J. Nutr. 2006, 136, 83-87.

129. Pawlosky, R.J.; Hibbeln, J.R.; Novotny, J.A.; Salem, N., Jr. Physiological compartmental analysis of $\alpha$-linolenic acid metabolism in adult humans. J. Lipid Res. 2001, 42, 1257-1265.

130. Brenna, J.T. Efficiency of conversion of $\alpha$-linolenic acid to long chain $n$-3 fatty acids in man. Curr. Opin. Clin. Nutr. Metab Care 2002, 5, 127-132.

131. Ezaki, O.; Takahashi, M.; Shigematsu, T.; Shimamura, K.; Kimura, J.; Ezaki, H.; Gotoh, T. Long-term effects of dietary $\alpha$-linolenic acid from perilla oil on serum fatty acids composition and on the risk factors of coronary heart disease in Japanese elderly subjects. J. Nutr. Sci. Vitaminol. 1999, 45, 759-772.

132. Ghafoorunissa; Vani, A.; Laxmi, R.; Sesikeran, B. Effects of dietary $\alpha$-linolenic acid from blended oils on biochemical indices of coronary heart disease in Indians. Lipids 2002, 37, 1077-1086.

133. Klein, V.; Chajes, V.; Germain, E.; Schulgen, G.; Pinault, M.; Malvy, D.; Lefrancq, T.; Fignon, A.; Le, F.O.; Lhuillery, C.; Bougnoux, P. Low $\alpha$-linolenic acid content of adipose breast tissue is associated with an increased risk of breast cancer. Eur. J. Cancer 2000, 36, 335-340.

134. Bougnoux, P.; Koscielny, S.; Chajes, V.; Descamps, P.; Couet, C.; Calais, G. $\alpha$-Linolenic acid content of adipose breast tissue: A host determinant of the risk of early metastasis in breast cancer. Br. J. Cancer 1994, 70, 330-334.

135. Fritsche, K.L.; Johnston, P.V. Effect of dietary $\alpha$-linolenic acid on growth, metastasis, fatty acid profile and prostaglandin production of two murine mammary adenocarcinomas. J. Nutr. 1990, 120, 1601-1609.

136. Hardman, W.E. Dietary canola oil suppressed growth of implanted MDA-MB 231 human breast tumors in nude mice. Nutr. Cancer 2007, 57, 177-183.

137. Mabasa, L.; Cho, K.; Walters, M.W.; Bae, S.; Park, C.S. Maternal dietary canola oil suppresses growth of mammary carcinogenesis in female rat offspring. Nutr. Cancer 2013, 65, 695-701. 
138. Menendez, J.A.; Vazquez-Martin, A.; Ropero, S.; Colomer, R.; Lupu, R. HER2 (erbB-2)-targeted effects of the omega-3 polyunsaturated fatty acid, $\alpha$-linolenic acid (ALA; 18:3n-3), in breast cancer cells: The "fat features" of the "Mediterranean diet" as an "anti-HER2 cocktail". Clin. Transl. Oncol. 2006, 8, 812-820.

139. Menendez, J.A.; Ropero, S.; Lupu, R.; Colomer, R. Dietary fatty acids regulate the activation status of Her-2/neu (c-erbB-2) oncogene in breast cancer cells. Ann. Oncol. 2004, 15, 1719-1721.

140. Mason, J.K.; Fu, M.H.; Chen, J.; Yu, Z.; Thompson, L.U. Dietary flaxseed-trastuzumab interactive effects on the growth of HER2-overexpressing human breast tumors (BT-474). Nutr. Cancer 2013, $65,451-459$.

141. Hirose, M.; Masuda, A.; Ito, N.; Kamano, K.; Okuyama, H. Effects of dietary perilla oil, soybean oil and safflower oil on 7,12-dimethylbenz (a) anthracene (DMBA) and 1,2-dimethyl-hydrazine (DMH)-induced mammary gland and colon carcinogenesis in female SD rats. Carcinogenesis 1990, 11, 731-735.

142. Chiu, L.C.; Wan, J.M. Induction of apoptosis in HL-60 cells by eicosapentaenoic acid (EPA) is associated with downregulation of bcl-2 expression. Cancer Lett. 1999, 145, 17-27.

143. Senzaki, H.; Iwamoto, S.; Ogura, E.; Kiyozuka, Y.; Arita, S.; Kurebayashi, J.; Takada, H.; Hioki, K.; Tsubura, A. Dietary effects of fatty acids on growth and metastasis of KPL-1 human breast cancer cells in vivo and in vitro. Anticancer Res. 1998, 18, 1621-1627.

144. Sauer, L.A.; Dauchy, R.T.; Blask, D.E.; Krause, J.A.; Davidson, L.K.; Dauchy, E.M. Eicosapentaenoic acid suppresses cell proliferation in MCF-7 human breast cancer xenografts in nude rats via a pertussis toxin-sensitive signal transduction pathway. J. Nutr. 2005, 135, 2124-2129.

145. Chambrier, C.; Bastard, J.P.; Rieusset, J.; Chevillotte, E.; Bonnefont-Rousselot, D.; Therond, P.; Hainque, B.; Riou, J.P.; Laville, M.; Vidal, H. Eicosapentaenoic acid induces mRNA expression of peroxisome proliferator-activated receptor gamma. Obes. Res. 2002, 10, 518-525.

146. Kang, K.S.; Wang, P.; Yamabe, N.; Fukui, M.; Jay, T.; Zhu, B.T. Docosahexaenoic acid induces apoptosis in MCF-7 cells in vitro and in vivo via reactive oxygen species formation and caspase 8 activation. PLoS One 2010, 5, doi:10.1371/journal.pone.0010296.

147. Blanckaert, V.; Ulmann, L.; Mimouni, V.; Antol, J.; Brancquart, L.; Chenais, B. Docosahexaenoic acid intake decreases proliferation, increases apoptosis and decreases the invasive potential of the human breast carcinoma cell line MDA-MB-231. Int. J. Oncol. 2010, 36, 737-742.

148. Chiu, L.C.; Wong, E.Y.; Ooi, V.E. Docosahexaenoic acid from a cultured microalga inhibits cell growth and induces apoptosis by upregulating Bax/Bcl-2 ratio in human breast carcinoma MCF-7 cells. Ann. N. Y. Acad. Sci. 2004, 1030, 361-368.

149. Tsujita-Kyutoku, M.; Yuri, T.; Danbara, N.; Senzaki, H.; Kiyozuka, Y.; Uehara, N.; Takada, H.; Hada, T.; Miyazawa, T.; Ogawa, Y.; et al. Conjugated docosahexaenoic acid suppresses KPL-1 human breast cancer cell growth in vitro and in vivo: Potential mechanisms of action. Breast Cancer Res. 2004, 6, R291-R299.

150. Connolly, J.M.; Gilhooly, E.M.; Rose, D.P. Effects of reduced dietary linoleic acid intake, alone or combined with an algal source of docosahexaenoic acid, on MDA-MB-231 breast cancer cell growth and apoptosis in nude mice. Nutr. Cancer 1999, 35, 44-49. 
151. Jourdan, M.L.; Maheo, K.; Barascu, A.; Goupille, C.; de Latour, M.P.; Bougnoux, P.; Rio, P.G. Increased BRCA1 protein in mammary tumours of rats fed marine omega-3 fatty acids. Oncol. Rep. 2007, 17, 713-719.

152. Bernard-Gallon, D.J.; Vissac-Sabatier, C.; ntoine-Vincent, D.; Rio, P.G.; Maurizis, J.C.; Fustier, P.; Bignon, Y.J. Differential effects of $n-3$ and $n-6$ polyunsaturated fatty acids on BRCA1 and BRCA2 gene expression in breast cell lines. Br. J. Nutr. 2002, 87, 281-289.

153. Bougnoux, P.; Chajes, V.; Germain, E.; Hubert, B.; Lhuillery, C.; Le, F.O.; Body, G.; Calais, G. Cytotoxic drug efficacy correlates with adipose tissue docosahexaenoic acid level in locally advanced breast carcinoma. Lipids 1999, 34, S109.

154. Bougnoux, P.; Hajjaji, N.; Ferrasson, M.N.; Giraudeau, B.; Couet, C.; Le, F.O. Improving outcome of chemotherapy of metastatic breast cancer by docosahexaenoic acid: A phase II trial. Br. J. Cancer 2009, 101, 1978-1985.

155. Rahman, M.M.; Veigas, J.M.; Williams, P.J.; Fernandes, G. DHA is a more potent inhibitor of breast cancer metastasis to bone and related osteolysis than EPA. Breast Cancer Res. Treat. 2013, $141,341-352$.

(C) 2014 by the authors; licensee MDPI, Basel, Switzerland. This article is an open access article distributed under the terms and conditions of the Creative Commons Attribution license (http://creativecommons.org/licenses/by/4.0/). 